\title{
PASTORAL KONSELING BAGI PASANGAN SUAMI ISTRI YANG TIDAK SEIMAN BERDASARKAN 1 KORINTUS 7:12-16
}

\author{
Mansyukur Waruwu
}

\section{PENDAHULUAN}

Pernikahan adalah rancangan Allah bagi hidup manusia. Dia-lah yang memprakarsai pernikahan.Allah yang memiliki inisiatif menyatukan seorang lakilaki dan seorang perempuan dalam pernikahan yang kudus. Allah berfirman; "tidak baik kalau manusia itu seorang diri saja, Aku akan menjadikan seorang penolong baginya yang sepadan dengan dia". 'Kata 'Aku akan menjadikan penolong baginya', memberikan pemahaman bahwa Allahlah yang lebih dahulu berinisiatif menjadikan penolong bagi Adam, Allah yang menyatukan Adam dengan penolongnya (hawa) dalam ikatan perkawinan. Dalam Kejadian pasal 2:22, lebih menjelaskan bahwa setelah Allah membentuk seorang perempuan dari tulang rusuk Adam, perempuan itu dibawaNya kepada Adam. ${ }^{2}$ Kata 'dibawanya kepada Adam' menunjukkan tindakan inisiatif Allah membentuk keluarga.Allah menjadikan seorang laki-laki dan seorang perempuan dan menyatukannya dalam sebuah ikatan perkawinan. Jadi pernikahan itu adalah prakarsa Allah.Yakub Susabda mengatakan; mengakui bahwa pernikahan merupakan inisiatif Allah berarti mengakui adanya tujuan Allah yang Agung dari pernikahan. ${ }^{3}$

Tindakan Allah menyatukan seorang laki-laki dan seorang perempuan dalam sebuah ikatan perkawinan memiliki tujuan yaitu agar manusia itu menerima berkatberkat Allah, memuliakanNya dengan melakukan perintahNya atau amanatNya. Alkitab menjelaskan bahwa setelah Allah menciptakan laki-laki dan perempuan menurut gambarNya, Allah memberkati mereka dan berfirman: "beranak cuculah dan bertambah banyak; penuhilah bumi dan taklukkanlah itu, berkuasalah atas ikanikan di laut dan burung-burung di udara dan atas segala binatang yang merayap di bumi". ${ }^{4}$ Kejadian 1:28 ini, yang disebut juga Amanat Budaya, yang menjelaskan tujuan pembentukan keluarga yaitu untuk memelihara ciptaan-Nya, meneruskan keturunan ilahi, dan mengembangkan apa yang sudah dilakukan Tuhan Allah atas bumi. Dengan kata lain, manusia diberi mandat untuk mengembangkan kebudayaan yang merefleksikan tindakan-tindakan dan sifat-sifat Pencipta. Alam semesta dibudayakan secara bertanggung-jawab untuk keperluan manusia. Nilai-nilai kerajaan Allah diresapkan dalam setiap aspek kehidupan umat manusia ${ }^{5}$.

Tuhan Yesus katakan; 'sebab itu seorang laki-laki akan meninggalkan ayahnya dan ibunya bersatu dengan istrinya sehingga keduanya menjadi satu daging. Demikianlah mereka bukan lagi dua melainkan satu. Karena itu apa yang telah dipersatukan oleh Allah tidak boleh diceraikan oleh manusia' ${ }^{6}$ Kata bersatu atau satu yang dimaksud tidak hanya memiliki makna bersatu secara jasmani tetapi juga

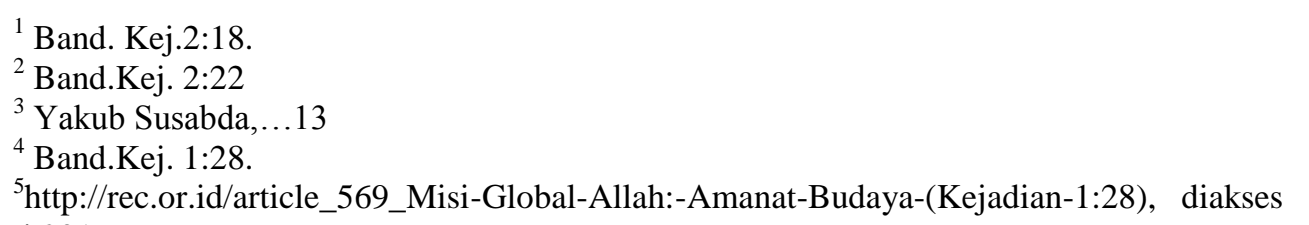
13 Februari 2017

${ }^{6}$ Band. Matius 19:5,6 
kesatuan secara rohani, artinya pasangan suami istri yang Allah kehendaki adalah pasangan suami-istri yang sama-sama beriman kepada Dia. Keduanya seimbang, sepadan, memiliki relasi yang intim dengan Allah, memiliki kematangan rohani yang baik, dengan demikian tujuan Allah dalam pernikahan itu tercapai, mereka mampu memuliakan Allah dan menikmati segala berkat Allah dalam pernikahan itu. Yakub Susabda mengatakan; Kehadiran Allah dalam hidup pernikahan memberikan kebahagiaan yang didasarkan atas kebenaran.Suami istri menikmati hidup pernikahan mereka oleh karena memang mereka mengalami berkat-berkat ilahi. Kehadiran Kristus dalam pernikahan itu memberikan hidup dalam kelimpahan (Yoh.10:10). ${ }^{7}$

\section{HAKIKAT PASTORAL KONSELING}

Untuk lebih mengerti dan memahami secara mendalam akan hakikat pastoral konseling, maka pada bagian ini, peneliti akan menguraikan; pengertian pastoral konseling, konselor dan konseli, dasar pastoral konseling, fungsi pastoral konseling dan tujuan pastoral konseling:

\section{Pengertian Pastoral Konseling}

Dengan memperhatikan istilah "Pastoral" dan istilah "Konseling", maka Pastoral Konseling" dapat didefenisikan sebagai pembimbingan yang dilakukan oleh seorang pastor atau gembala jemaat kepada jemaat (konseli) agar mereka mampu menghadapi, memecahkan dan menyelesaikan masalahnya. Pelayanan pembimbingan tersebut harus dilakukan secara total dan sungguh-sungguh karena membutuhkan proses.

Untuk lebih memahami pengertian pastoral konseling secara baik, Yakub B. Susabda dalam bukunya Pastoral Konseling, Secara rinci menyebutkan bahwa:

Pastoral Konseling adalah hubungan timbal balik (interpersonal relationship) antara hamba Tuhan (pendeta, penginjil, dsb) sebagai konselor dengan konselinya (klien, orang yang minta bimbingan), dalam mana konselor mencoba membimbing konselinya ke dalam suatu suasana percakapan konseling yang ideal (conductive atmosphere) yang memungkinkan konseli itu betul-betul dapat mengenal dan mengerti apa yang sedang terjadi pada dirinya sendiri, persoalannya, kondisi hidupnya, di mana ia berada, dsb; sehingga ia mampu melihat tujuan hidupnya dalam relasi dan tanggung jawabnya pada Tuhan dan mencoba mencapai tujuan itu dengan takaran, kekuatan dan kemampuan seperti yang sudah diberikan Tuhan kepadanya. ${ }^{8}$

Pastoral konseling adalah sebagai hubungan komunikasi timbal balik (interpersonal relationship) antara hamba Tuhan atau gembala dengan konselinya karena Pastoral Konseling adalah suatu dialog - dan bukan monolog, yang terjadi antara hamba Tuhan dan konselinya yang melibatkan seluruh aspek kehidupan mereka masing-masing. Sebagai konselor, hamba Tuhan tidak bertindak sebagai pengkhotbah di depan umum yang memberikan firman Tuhan, hanya memberi nasihat, teguran dan ajaran saja kepada konselinya tetapi sebagai konselor, hamba

\footnotetext{
${ }^{7}$ Yakub Susabda, Pembinaan Keluarga Kristen, (Bandung: Mitra Pustaka, 2004), 19.

${ }^{8}$ Yakub B. Susabda, Pastoral Konseling Jilid I, (Malang: Gandum Mas,1985), 4
} 
Tuhan berhadapan langsung (muka) dengan konselinya sebagai dua pribadi yang utuh, yang masing-masing memiliki hak dan kebebasan untuk mengekspresikan dirinya.

Oleh sebab itu, seorang hamba Tuhan sebagai seorang konselor harus mengembangkan disiplin dan keahlian dalam pelayanan ini agar konseli melihat dirinya secara utuh di hadapan Tuhan dan mencapai tujuan hidupnya berdasarkan kemampuan yang sudah Tuhan berikan kepadanya. Dengan demikian, konseli menemukan kembali jati dirinya di hadapan Tuhan dan di hadapan sesamanya manusia serta mau taat dan memuliakan Tuhan dalam hidupnya.

\section{HAKIKAT PASANGAN SUAMI ISTRI YANG TIDAK SEIMAN}

Untuk lebih mengetahui dan memahami hakikat ${ }^{9}$ pasangan suami istri yang tidak seiman, pada bagian ini akan diuraikan pasangan suami istri menurut Alkitab, pasangan suami yang tidak seiman, dan pasangan suami istri yang tidak seiman berdasarkan 1 Korintus 7:12-16.

\section{Dasar Pasangan suami istri dalam pernikahan Pernikahan Kristen}

Alkitab menjelaskan tentang hakikatpasangan suami istri dalam pernikahan Kristen seperti yang dibahas dalam pembahasan berikut;

\section{Desain Allah}

Bersatunya seorang laki-laki dan seorang perempuan sebagai pasangan suami istri dalam pernikahan adalah desain ${ }^{10}$ Allah. Allah yang menyatukan laki-laki dan perempuan dalam sebuah pernikahan yang telah Ia berkati. Bersatunya seorang pria dan seorang wanita dalam ikatan pernikahan adalah mutlak pekerjaan Allah sendiri. Ia-lah yang mendesain pernikahan. Jhon Stott berkata; Perkawinan bukanlah temuan

9 Hakikat artinya intisari atau dasar.kenyataan yg sebenarnya (sesungguhnya), lih.http://kbbi.web.id/hakikat. diakses pada tanggal 15 Februari 2017. Kata hakikat (Haqiqat) merupakan kata benda yang berasaldari bahasa Arab yaitu dari kata "Al-Haqq", dalam bahasa indonesia menjadi kata pokok yaitu kata "hak" yang berarti milik (ke $\neg$ punyaan), kebenaran, atau yang benar-ᄀbenar ada, sedangkan secara etimologi Hakikat berarti inti sesuatu, puncak atau sumber dari segala sesuatu. Dapat disimpulkan bahwa Hakikat adalah kalimat atau ungkapan yang digunakan untuk menunjukkan makna yang yang sebenarnya atau makna yang paling dasar dari sesuatu seperti benda, kondisi atau pemikiran, Akan tetapi ada beberapa yang menjadi ungkapan yang sudah sering digunakan dalam kondisi tertentu, sehingga menjadi semacam konvensi, hakikat seperti disebut sebagai hakikat secara adat kebiasaan. Lih.http://www.definisi-pengertian.com/2015/01/definisi-dan - pengertian-hakikat.html, di akses pada tanggal 15 Februari 2017.

${ }^{10}$ Desain biasa diterjemahkan sebagai seni terapan, arsitektur, dan berbagai pencapaian kreatif lainnya. Dalam sebuah kalimat, kata "desain" bisa digunakan, baik sebagai kata benda maupun kata kerja. Sebagai kata kerja, "desain" memiliki arti "proses untuk membuat dan menciptakan obyek baru". Sebagai kata benda, "desain" digunakan untuk menyebut hasil akhir dari sebuah proses kreatif, baik itu berwujud sebuah rencana, proposal, atau berbentuk benda nyata. (lih.https://id.wikipedia.org/wiki/Desain, di akses pada tanggal 25 April 2018), KKBI mengartikan kata de-sain /désain/ $n 1$ kerangka bentuk; rancangan: --mesin pertanian itu dibuat oleh mahasiswa fakultas teknik; 2 motif; pola; corak (: https://artikbbi.com/desain, 2016) di akses 25 April 2018. Jika kata desain dikaitkan dengan pernikahan maka dapat diartikan pernikahan adalah bentukan, rancangan atau Karya Allah. 
manusia, perkawinan sudah ditetapkan Allah pada masa sebelum kejatuhan manusia ke dalam dosa. ${ }^{11}$.

Sutjipto Subeno juga menegaskan, bahwa Pernikahan adalah lembaga yang ditetapkan oleh Allah, bukanlah hasil rekayasa manusia yang ingin menikah. ${ }^{12} \mathrm{Hal}$ senada juga disampaikan oleh R.C Sproul, bahwa pernikahan bukanlah hasil dari perkembangan kebudayaan.Institusi pernikahan ditetapkan seiring dengan penciptaan itu sendiri. ${ }^{13} \mathrm{Jadi}$, Pernikahan adalah gagasan Allah, desain atau karya Allah dalam penciptaan-Nya. Dalam mazmur 127:1 yang mengatakan bahwa; "Jikalau bukan Tuhan yang membangun rumah, sia-sia usaha orang yang membangunnya. Istilah membangun berasal dari Bahasa Yunani 'banah' yang berarti "build" yaitu bangunan. ${ }^{14}$ Ayat ini berkaitan erat dengan rumah tangga (keluarga) umat-Nya dimana Tuhan sendiri sebagai arsitek tunggal yang membangun rumah tangga (keluarga).

Lembaga setelah Allah menciptakan manusia pertama Adam adalah keluarga, Allah berfirman dalam kitab Kejadian Pasal 2:18; Tidak baik kalau manusia itu seorang diri saja, Aku akan menjadikan penolong baginya, yang sepadan dengan dengan dia, Kemudian dalam Kejadian Pasal 2:21-22, berkata; Lalu TUHAN Allah membuat manusia itu tidur nyenyak; ketika Ia tidur, TUHAN Allah mengambil salah satu rusuk dari padanya, lalu menutup tempat itu dengan daging, dan dari rusuk yang diambil Tuhan Allah dari manusia itu, dibangun-Nyalah seorang perempuan, lalu dibawanya kepada manusia itu. Sebab itu seorang laki-laki akan meninggalkan ayah dan ibunya dan bersatu dengan istrinya sehingga keduanya menjadi satu daging (Ke. 2: 24).

Ayat-ayat tersebut diatas menunjukkan bahwa Allahlah yang mendesain pernikahan, Ia-lah yang merencanakan bersatunya seorang laki-laki dan seorang perempuan dalam sebuah keluarga. Allah jadikan laki-laki dan Perempuan kemudian disatukan dan diberkatinyalah mereka (Kej.1:28a).

\section{Kesatuan Seumur Hidup}

Alkitab menjelaskan bahwa pernikahan adalah kesatuan seumur hidup antara seorang laki-laki dan seorang perempuan yang telah Ia berkati. Matius 19:5,6 mengatakan; dan firman-Nya; sebab itu laki-laki akan meninggalkan ayah dan ibunya dan bersatu dengan istrinya, sehingga keduanya menjadi satu daging. Demikianlah mereka bukan lagi dua, melainkan satu. Karena itu apa yang telah dipersatukan oleh Allah, tidak boleh diceraikan oleh manusia. Disini Tuhan Yesus menegaskan bahwa pernikahan itu seumur hidup. Allah tidak merancang perceraian tetapi ia merancang pernikahan itu seumur hidup, sampai kematian memisahkan. Menjadi satu daging' menjelaskan kesatuan antara suami-istri secara jasmani. Dan kesatuan itu adalah kesatuan seumur hidup, dimana manusia tidak boleh menceraikannya.

11 Jhon Stott, Isu-isu Global: Menantang kepemimpinan Kristiani, (Jakarta: Yayasan Komunikasi Bina kasih/OMF, 1984), 368

${ }^{12}$ Sutjipto Subeno, Indahnya Pernikahan Kristen, (Surabaya: Momentum, 2008), 13.

13 Sproul R.C, Discovering the intimate Marriage, (Minnesota: Bethany Fellowship, Inc, 1975), 113-114.

${ }^{14}$ Jay P. Green, The Interlinear Bible Hebrew-English, (Michigan: Baker Book House, 1982), 58 
Rasul Paulus mengatakan bahwa Istri terikat selama suaminya hidup. Kalau suaminya telah meninggal, ia bebas untuk kawin dengan siapa saja yang ia kehendaki, asal orang itu adalah seorang yang percaya. (1 Korintus 7:2-3), Dalam Roma 7:2, Rasul Paulus juga mengatakan Bahwa Sebab seorang istri terikat oleh hukum kepada suaminya selama suaminya hidup. Akan tetapi apabila suaminya itu mati, bebaslah ia dari hukum yang mengikatnya kepada suaminya itu. Bahkan Rasul Paulus menjelaskan tujuan simbolis dari hubungan suami-istri adalah untuk merefleksikan hubungan antara Kristus dengan gerejaNya. ${ }^{15}$

Dan jikalau ia bercerai ia harus tetap hidup tanpa suami atau berdamai dengan suaminya" (1 Korintus 7:10-11). Bahkan "kalau ada ada seorang yang saudara beristrikan seorang yang tidak beriman dan perempuan itu mau hidup bersama-sama dengan dia, janganlah saudara itu menceraikan dia. Demikian juga, "kalau ada seorang istri bersuamikan seorang yang tidak beriman dan laki-laki itu mau hidup bersama-sama dengan dia, janganlah ia menceraikan laki-laki itu (1 Kor.7:12-13). Kelima; Perceraian membatallkan seorang penilik jemaat.Salah satu kualifikasi bagi seorang penilik jemaat adalah bahwa haruslah dia "suami dari satu istri (1 Timotius 3:2).Keenam; Pasangan pertama seseorang adalah pasangan yang benar. Ketika wanita samaria berbicara kepada Yesus, " Aku tidak mempunyai suami." Jawah Yesus; Tepat katamu, bahwa engkau tidak mempunyai suami, sebab engkau sudah mempunyai lima suami dan yang sekarang yang ada padamu, bukanlah suamimu (Yohanes 4:1718). Ayat ini diambil untuk menyiratkan bahwa pasangan pertama seseorang adalah satu-satunya pasangan yang benar.Ketujuh; Perceraian melanggar tipologi yang sakral. Menurut Paulus, seorang istri untuk suaminya adalah sama dengan gereja untuk Kristus (Efesus 5:32). ${ }^{16}$

Karena itu, perceraian melanggar tipologi yang indah dari pernikahan sorgawi antara Kristus dan mempelai-Nya yaitu gereja.Kenyataan bahwa Allah memperlakukan tindakan yang melanggar sesuatu yang berifat sakral secara serius, dapat dilihat di dalam hukuman-Nya atas Musa karena memukul batu karang tersebut dua kali (Bilangan 20:9-20). ${ }^{17}$

Dari beberapa penjelasan di atas menegaskan bahwa pernikahan adalah seumur hidup. Dan karena tidak ada dasar bagi perceraian maka perceraian adalah dosa dan pernikahan kembali dengan orang yang sudah bercerai adalah keliru. ${ }^{18}$ Jadi, Pernikahan itu seumur hidup, manusia tidak boleh menceraikan apa yang telah dipersatukan oleh Allah dengan alasan apapun kecuali karena kematian.

\section{Seiman}

Pernikahan adalah suatu lembaga atau institusi yang sakral dan unik yang dibentuk oleh Allah. Pernikahan bukanlah akibat dosa, sebab kejatuhan manusia dalam dosa terjadi setelah Allah membentuk lembaga pernikahan.Pernikahan merupakan rancangan Allah yang unik dari mulanya karena di dalamnya terkandung

\footnotetext{
${ }^{15}$ Efesus 5:23

${ }^{16}$ Norman L. Geisler, Etika Kristen..., 361

${ }^{17}$ Ibid., 361

${ }^{18}$ Norman L. Geisler, Etika Kristen..., 361
} 
rahasia Allah yang besar menyangkut relasi Allah dengan jemaat-Nya. ${ }^{19}$ Sutjipto Subeno mengatakan; Pernikahan merepresentasikan hubungan antara Allah dan umat-Nya, antara Kristus dan jemaaat. ${ }^{20}$. Relasi suami istri dalam pernikahan menunjukkan relasi antara Allah dengan manusia, antara Kristus dengan jemaatNya.Jadi, dapat disimpulkan bahwa pasangan suami-istri dalam keluarga Kristen haruslah seiman.

Allah menghendaki pasangan suami-istri yang seiman. Seorang laki-laki dan seorang perempuan bersatu dalam pernikahan yang kudus adalah Prakarsa Allah yang bertujuan agar dalam keluarga itu bersama-sama melakukan kehendak-Nya untuk kemuliaan-Nya. Allah menghendaki sebuah relasi yang baik antara Dia dengan keluarga. Dalam efesus 6:23, mengatakan; 'karena suami adalah kepala istri sama seperti Kristus adalah kepada jemaat. Kata 'Kristus adalah kepala jemaat' menekankan bahwa pemimpin keluarga Kristen adalah Allah itu sendiri, Itulah sebabnya alasan mengapa Allah menghendaki pernikahan yang seiman. Sebab kepala keluarga adalah Kristus.

Rasul Paulus mengatakan; Janganlah kamu menjadi pasangan yang tidak seimbang. ${ }^{21}$ Prinsip ini digunakan oleh Paulus untuk menekankan bahwa tidak boleh dan sungguh bertentangan bila orang beriman merupakan pasangan yang tidak seimbang (menikah) dengan orang yang tidak beriman kepada Yesus Kristus. Orang Kristen hanya boleh menikah dengan orang yang seiman, jika tidak maka mereka tidak akan mengalami secara sempurna berkat-berkat Allah dalam pernikahannya.

Suami istri yang sama-sama takut pada Tuhan akan sama-sama menerima anugerah hidup sejati dari Allah. Yakub susabda mengatakan; Kehadiran Allah dalam hidup pernikahan memberikan kebahagiaan yang didasarkan atas kebenaran.Suami istri menikmati hidup pernikahan mereka oleh karena memang mereka mengalami berkat-berkat ilahi. Kehadiran Kristus dalam pernikahan tersebut memberikan 'hidup dalam kelimpahan', ${ }^{22}$ Hal ini menjelaskan bahwa Pasangan suami istri yang beriman kepada Tuhan Yesus, akan mengalami pertolongan Allah yang sempurna, sebab pernikahannya dirancang oleh Allah bukan hanya untuk kesukaanNya tetapi juga untuk kebaikan manusia itu sendiri.

Ketika Tuhan Yesus menjelaskan tujuan sejati pernikahan, Ia menekankan poin bahwa Allah sendirilah yang mempersatukan pria dan wanita dalam pernikahan "Demikianlah mereka bukan lagi dua melainkan satu. Karena itu apa yang telah dipersatukan oleh Allah, tidak boleh diceraikan oleh manusia" ${ }^{\text {,23 }}$, kata bahasa Yunani yang Yesus gunakan untuk menguraikan penyatuan pasangan yang menikah adalah

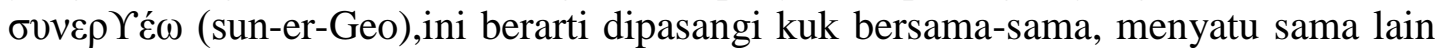
dan bersatu dalam pernikahan. ${ }^{24} \mathrm{Jadi}$, bersatunya orang Kristen dengan orang yang tidak percaya dalam pernikahan akan mengakibatkan tekanan dalam hidup pasangan suami istri tersebut tetapi dengan bersatunya dua orang Kristen dalam sebuah pernikahan menjadikan kuk itu terasa ringan. Orang Kristen hanya boleh menikah

\footnotetext{
${ }^{19}$ Efesus 5:32

${ }^{20}$ Sutjipto Subeno, Indahnya Pernikahan Kristen..., 22

${ }^{21} 2$ Korintus 6:14

${ }^{22}$ Yakub Susabda, Pembinaan Keluarga Kristen...,19

${ }^{23}$ Matius 19:6

24 ___ Memahami Dasar-Dasar Alkitabiah Bagi Pernikahan, (Jakarta; IBLP, 2006), 12
} 
dengan orang Kristen, jika tidak, mereka akan mengenakan kuk yang tidak seimbang dengan orang yang tidak percaya. Bila kedua pasangan yang menikah itu bertumbuh di dalam Tuhan dan belajar semakin dalam tentang Dia, kuk Pernikahan itu menjadi mudah dan ringan. ${ }^{25}$

Jadi, pasangan suami istri dalam pernikahan haruslah seiman, bukan saja hanya untuk bersama-sama melakukan kehendak Allah melainkan menyangkut masa depan kebahagiaan pasangan suami istri tersebut. Pasangan yang seiman bukan berarti mereka tidak akan mengalami masalah, mereka mungkin menghadapi masalah namun tidak seperti masalah yang dihadapi oleh pasangan suami istri yang tidak seiman. Sebab Tuhan memberikan perhatian khusus bagi keluarga Kristen, sebab Dia adalah kepalanya.

\section{Monogami}

Pasangan suami istri dalam pernikahan Kristen harus monogami artinya satu orang laki-laki dan satu orang perempuan. Allah yang telah merancangkan pernikahan monogami, ketika Allah membentuk keluarga, Ia hanya menyatukan satu orang pria dan satu orang perempuan. Dalam kejadian 1:27 dikatakan; Maka Allah menciptakan manusia itu menurut gambar-Nya, menurut gambar Allah diciptakanNya dia; laki-laki (ish) dan perempuan (ishsha) diciptakan-Nya mereka”, selanjutnya dalam Kejadian 2:24, berkata; Sebab itu seorang laki-laki akan meninggalkan ayahnya dan ibunya dan bersatu dengan istrinya sehingga keduanya menjadi satu daging. Kata 'seorang' adalah kata tunggal, menunjukkan satu orang dan kemudian kalimat 'bersatu dengan istrinya sehingga keduanya menjadi satu daging' menegaskan bahwa pasangan suami istri adalah satu orang laki-laki dan satu orang perempuan. Rasul Paulus menegaskan kepada jemaat di korintus bahwa pernikahan itu adalah monogami dengan mengatakan "baiklah setiap laki-laki (bentuk tunggal) mempunyai istrinya sendiri (bentuk tunggal) dan setiap perempuan mempunyai suaminya sendiri" (1 Korintus 7:2). Erich Unarto mengatakan; Tuhan tidak menciptakan Hawa-hawa, tetapi hanya menciptakan satu Hawa. ${ }^{26}$ Monogami adalah asli aturan Allah dan itulah hubungan yang sewajarnya. ${ }^{27}$

Jadi Pasangan suami istri dalam pernikahan kristen adalah pasangan yang sifatnya monogami, bukan poligami dan heteroseksual (berbeda jenis kelamin) ataupun homoseksual (sesama jenis kelamin). Laki-laki tidak boleh memiliki istri lebih dari pada satu demikian sebaliknya istri tidak boleh memiliki suami lebih dari satu kecuali jika maut (kematian jasmani) memisahkan.

\section{Kudus}

Pernikahan adalah sesuatu yang sakral atau kudus di mata Allah. Yakub Susabda mengatakan bahwa ;pernikahan adalah sesuatu yang sakral dihadapan Allah, oleh sebab itu beratus ratus kali Alkitab mengingatkan anak anak-anak Tuhan untuk memelihara kesucian kehidupan dari perzinahan dalam bentuk apapun (Ibr.13:14). ${ }^{28}$

\footnotetext{
${ }^{25}$ Ibid., 12

${ }^{26}$ Erich Unarto, Hidup Dalam Etika Kristen, (Jakarta: Pustaka Sorgawi, 2007), 37

27 J. A. Thomson (Ed), Ensiklopedi Alkitab Masa Kini Jilid I, (Jakarta: Yayasan Bina Kasih
} OMF, 2007), 154

${ }^{28}$ Pembinaan Keluarga Kristen..., 75. 
Karena Pernikahan Kristen adalah sesuatu yang kudus di hadapan Allah maka Allah menganggap suatu dosa bagi mereka yang mencemarkan ikatan pernikahan, bahkan hubungan seksual pra-nikah maupun hubungan seksual sebagai perselingkuhan dianggap sebagai perzinahan (Im. 18,19, 20; Kis. 15:20; 1 Kor. 6:18; Kel. 20:14). ${ }^{29}$ Penulis Kitab Ibrani menegaskan bahwa pernikahan adalah suatu yang kudus dan tidak boleh dicemarkan. "Hendaklah kamu semua penuh hormat terhadap perkawinan dan janganlah kamu mencemarkan tempat tidur, sebab orang-orang sundal dan penzinah akan dihakimi Allah" (Ibr. 13:4).

Mengingat pernikahan adalah sesuatu yang suci, maka tidak boleh dinodai, dicemarkan oleh hubungan pasangan suami istri yang tidak berkenan kepada Tuhan. Kembali Yakub susabda menegaskan bahwa "Apa yang dihalalkan manusia tidak dibenarkan oleh Allah, oleh sebab itu apa yang dunia anggap "wajar" (Mis. Masturbasi dan fantasi perjinahan) bagaimanapun alasannya harus ditanggalkan dari kehidupan orang-orang-orang percaya. Matius 5:27-28 menegaskan bahwa apa yang ada di dalam hati dan pikiranlah yang menentukan apakah kelakuan seorang itu dapat disebut perjinahan atau bukan". 30

Selain itu, karena hubungan pasangan suami istri dalam pernikahan kristen adalah representasi hubungan Tuhan Yesus dengan jemaatNya maka hubungan itu adalah kudus, karena tidak mungkin gelap dan terang bersatu. John Piper mengatakan, pernikahan adalah kudus, melampaui yang dapat dibayangkan kebanyakan orang, sebab ini adalah unik dari Allah, gambaran yang dramatis dari relasi Allah dengan umatNya, dan pernyataan kemuliaan Allah. ${ }^{31}$

\section{Peranan Pasangan Suami Istri Menurut Alkitab}

Alkitab menjelaskan tentang peranan suami dan Istri dalam keluarga Kristen. Peranan yang dimaksud adalah sebagaimana dijelaskan dalam bagian berikut;

\section{Peranan Suami}

Peranan suami dalam rumah tangga Kristen adalah sebagai kepala, imam dan ayah bagi anak-anak.

\section{Kepala Bagi Istri}

Suami memang dicipta dengan tugas sebagai kepala bagi Istrinya.Ia adalah kepala bagi istrinya dan keluarganya. Ia dicipta untuk menjalankan tugas sebagai kepala dalam rumah tangganya, Sutjipto Subeno mengatakan;

Pria memang dicipta dengan tugas sebagai kepala bagi istrinya (1Kor.11:3) dan ia harus bertanggungjawab penuh untuk seluruh keluarganya. Oleh karena itu, pria diberikan kemampuan melakukan orientasi kerja dan lebih rasional dari wanita.Tugas pengaturan kesejahteraan seluruh keluarga ada ditangan Pria. Pria yang harus mengarahkan seluruh kehidupan keluarganya, bekerja keras dan menyediakan nafkah bagi seluruh keluarganya, sehingga seluruh

\footnotetext{
${ }^{29}$ Robert Borrong, Etika Seksual Kontemporer, (Bandung: Ink Media, 2006), 17

${ }^{30}$ Yakub Susabda, Pembinaan Keluarga Kristen..., 75

${ }^{31}$ John Piper, Apa Yang Yesus Tuntut Dari Dunia, (Malang: Literatur SAAT, 2012), 337
} 
keluarganya akan merasa aman hidup dibawah naungannya. Ia menjadi wakil Kristus bagi jemaat. ${ }^{32}$

Yakub Susabda mengatakan; Keunikan laki-laki sebagai kepala dan perempuan sebagai penolong yang sepada $100 \%$ terletak pada "sifat panggilan Allah' saja.Yaitu Allah yang Mahabijak, Mahatahu dan berencana menghendaki tujuan pernikahan manusia tercapai melalui cara/jalan-Nya sendiri.Ia memanggil laki-laki (siapapun dia, bagaimanapun bakat atau latar belakangnya) untuk berperan sebagai kepala, pengambil keputusan, inisiator, pelindung, organisator, dan developer. ${ }^{33}$ Dapat dimengerti bahwa menjadi kepala bukanlah karena keinginan laki-laki ataupun perempuan tetapi karena panggilan Allah.

Suami sebagai kepala memiliki tanggungjawab terhadap istrinya dan keluarganya. Vivian A. Soesilo, mengatakan bahwa; "Suami sebagai kepala keluarga bertanggung jawab terhadap istrinya atau keluarganya.Suami diminta memenuhi kewajibannya sebagai kepala keluarga dengan penuh kasih, setia, pengabdian, penyerahan dan pengorbanan seperti Kristus terhadap jemaat-Nya. Sebagai kepala keluarga suami melindungi istri dan anak-anaknya" 34

Dalam Efesus 5:23, berkata; Karena suami adalah kepala istri sama seperti Kristus adalah kepala jemaat. Dialah yang menyelamatkan Tubuh. Disini Paulus menegaskan bahwa suami diberikan tanggung jawab sebagai kepala bagi istri atau keluarga. Sebagai kepala berarti ia adalah pemimpin keluarganya yang memiliki tanggungjawab penuh pertumbuhan iman istri dan keluarganya. Dalam Alkitab penuntun Hidup berkelimpahan menjelaskan tanggungjawab itu sebagai berikut;

1). Penyediaan kebutuhan rohani dan kebutuhan rumah tangga bagi keluarganya (kej.3:16-19; 1 Tim.5:8). 2) Kasih, perlindungan dan perhatian untuk kesejahteraannya sebagaimana Kristus mengasihi gereja (Efesus 5:25-33). 3). Hormat pengertian, penghargaan dan perhatian (Kol.3:19; 1 Pet 3:7). 4). Kesetiaan mutlak terhadap ikatan pernikahan (Efesus 5:31). ${ }^{35}$

Panggilan sebagai kepala bukan berarti menjadi seorang dengan wewenang raja atau diktator yang bisa memaksakan kehendak pribadinya sendiri terhadap istri atau keuarganya. Sebagai kepala, panggilan seorang suami adalah sama seperti Kristus yang rela menyerahkan diri-Nya untuk jemaat yang dikasihi-Nya. Kalaupun, misalnya ia suami yang sangat berbakat yang dapat melaksanakan semuanya sendiri, ia harus sadar bahwa panggilannya yang terutama adalah justru terletak pada kerelaan untuk ditolak. ${ }^{36}$ Panggilan suami sebagai kepala bagi istrinya dan keluarganya harus dilaksanakan dengan penuh tanggungjawab, dilaksanakan dalam kasih, perhatian, kelembutan dan tenggangrasa terhadap orang yang dipimpinnya.

\section{Sebagai Imam Dalam Keluarga}

Suami adalah imam dalam keluarga. Edwin Louis Cole dalam bukunya 'Kesempunaan Seorang Pria' yang diringkas oleh S.Setiawati, mengatakan;

\footnotetext{
${ }^{32}$ Sutjipto Subeno, Indahnya Pernikahan Kristen, (Surabaya; Momentum, 2008), 52

${ }^{33}$ Yakub Subabda..., 45-46

${ }^{34}$ Vivia A. Seosilo..., 68

$35 \ldots$ _. Alkitab Penuntun Hidup Berkelimpahan..., 1972

36 Yakub Susabda..., 45
} 
"Allah sudah menentukan bahwa yang menjadi imam dalam sebuah keluarga adalah pria.Oleh karena itu, jika Anda adalah seorang pria, Anda adalah seorang imam.Tidak masalah apakah Anda seorang sarjana teologia atau tidak. Tugas seorang imam adalah melayani Tuhan dan melayani orang-orang yang dipercayakan kepadanya: istri dan anak-anak. Pelayanan kaum pria harus diwujudkan dalam tindakan nyata seperti yang diberikan Allah dalam Alkitab.Setiap laki-laki harus diperlengkapi sebagai seorang imam agar dapat melayani di dalam keluarga.,37

Suami sebagai imam yang dimaksud bukanlah dalam arti jabatan tetapi lebih kepada fungsi imamnya. Para imam dalam Perjanjian Lama mewakili umat dihadapan Allah. Para imam diangkat oleh Allah (Keluaran 28:1, Bilangan 3:10), bertindak atas nama manusia dalam hal-hal yang berhubungan dengan Allah. Sebagai contoh, Imam harus mempersembahkan kurban dan persembahan tersebut karena dosa, memohon doa syafaat bagi umat yang diwakilinya, dan memberkati umat-Nya. Apabila orang Israel berbuat dosa dan datang kepada seorang imam, maka tugas pertama imam adalah mendengar dosa yang dilakukan orang tersebut ataupun masalah sengketa diantara mereka. Setelah itu, baru imam memutuskan, menyembelih tekukur, lembu atau burung dara tergantung besarnya dosa serta bersyafaat bagi orang tersebut meminta pendamaian dari Tuhan ${ }^{38}$.

Suami memiliki peran sebagai imam dalam keluarga. Memimpin keluarganya ke dalam kebenaran menjadi tanggung jawab yang utama dan pelayanan keimamam seorang laki-laki (suami). Suami sebagai imam bagi istri dan anak-anaknya, harus memimpin, mendengarkan, berdoa atau bersyafaat seluruh anggota keluarganya. Oleh karena itu dalam pernikahan Kristen suami dituntut untuk sungguh-sungguh mengasihi Tuhan sehingga mampu memimpin, menggembalakan seluruh anggota keluarganya ke dalam kebenaran Allah. Suami yang tidak mengasihi Tuhan, tidak percaya kepada Kristus maka peranan sebagai imam tidak dapat dijalani dengan baik sehingga kebaikan dan kenyamanan hidup dalam keluarga, sulit tercapai.

\section{Ayah Bagi Anak-Anak}

Panggilan menjadi ayah adalah unik dan sangat kuat. Menjadi ayah adalah tugas penting bagi laki-laki. Tugas ini memposisikan seorang ayah sebagai sosok yang benar-benar dibutuhkan. Masa depan diri sendiri, keluarga bahkan seluruh masyarakat tergantung pada tugas yang di lakukan sebagai seorang ayah. ${ }^{39}$

Ayah adalah pemimpin dalam rumah tangga Kristen. Alkitab menetapkan seorang laki-laki (Ayah) tidak hanya sebagai kepala bagi istri tetapi juga kepala atau pemimpin bagi anak-anaknya (Efesus 5:23). Memimpin keluarga ke dalam kebenaran menjadi tanggungjawab yang utama seorang ayah dalam tugas imamannya. Tindakan mulia seorang ayah adalah memberikan dirinya kepada anakanaknya, dan kepada Allah. ${ }^{40}$ Seorang ayah harus memimpin anak-anaknya ke dalam

${ }^{37}$ Edwin Louis Cole, Kesempurnaan Seorang Pria, (Jakarta: Metanoia, 2011), 80-90. 2017), 70

38 Jarot Wijanarko, Pemulihan Pria sejati dan wanita Bijak, (Jogjakarta: Penerbit ANDI,

${ }^{39}$ Gregory W. Slayton, Be A Better Dad Today, ( Jakarta: Persekutuan Gereja-Gereja Tionghoa Indonesia, 2015), 11

${ }^{40}$ Edwin Lois Cole...., 118. 
hubungan yang kuat dengan Allah.John Piper menegaskan bahwa di dalam pernikahan, ayah mempunyai tanggungjawab sebagai pemimpin untuk membesarkan anak-anak di dalam ajaran dan nasehat Tuhan. ${ }^{41}$

Selain itu, harus dipahami bahwa Kedudukan ayah dalam keluarga Kristen adalah sebagai wakil Allah.Allah telah menetapkan ayah sebagai kepala dan wakil Allah dalam keluarga (Efesus 5:23). Dengan kedudukan sebagai wakil Allah sekaligus memiliki amanat untuk memimpin keluarga sesuai dengan kehendak dan tujuan Allah dalam keluarga. Kedudukan tersebut sebagai lanjutan wewenang yang telah Allah berikan di taman eden (Kej. 1:26-28; 2:15). Kedudukan Ayah sebagai wakil Allah juga mengingatkan kepada faktor keterbatasan dan ketergantungan ayah kepada Kristus dalam mengatur rumah tangga. Jadi, seorang ayah sejati harus benarbenar memiliki iman yang kuat, mengasihi "Kepala" nya dengan sepenuh hati sehingga ia mampu memimpin keluarganya kepada kebenaran.

\section{Peranan Istri}

Meskipun laki-laki (suami) dan perempuan (istri) dicipta menurut gambar dan rupa Allah (Kej. 1:27), namun keduanya memiliki peranan yang berbeda.Keduanya memiliki keunikan yang berbeda.Pada bagian ini peneliti membahas peranan istri dalam rumah tangga Kristen.

\section{Penolong}

Seorang Wanita dicipta untuk menjadi seorang penolong bagi Pria (suami). Istri adalah seorang penolong bagi suaminya.Alkitab Berkata; Tidak baik kalau manusia itu seorang diri. Aku akan menjadikan seorang penolong baginya (Kej.2:18). Istri telah ditetapkan Tuhan sebagai penolong bagi suaminya, dan tugas ini adalah panggilan. Status sebagai penolong bukanlah karena keinginan laki-laki atau perempuan itu sendiri melainkan diberikan oleh Allah sendiri (Kej.2:18). D. Scheunemann, mengatakan bahwa Gelar penolong diberikan oleh Allah sendiri (Kejadian 2:18). Kata penolong dalam bahasa Ibrani "Ezer", kata ini juga di jumpai dalam kata Ebenhaezer, sampai disini Tuhan telah menolong. ${ }^{42}$ Seorang istri harus mampu menolong suaminya melaksanakan kehendak Allah.Sebagai penolong yang sepadan, panggilan seorang istri adalah menolong suaminya untuk bisa menjadi kepala dalam segala peranannya. ${ }^{43}$ Suaminya merasakan pertolongan Tuhan dengan adanya Istri yang Tuhan tempatkan disisinya sebagai penolong.Penolong Berarti mengangkat, menyelamatkan, memberikan jalan keluar, menghibur dan bukan menjatuhkan atau mengkritik serta membuat malu. ${ }^{44}$

Seorang Istri harus menyadari hakikatnya sebagai penolong yang sepadan, penolong yang berharga yang ditempatkan Allah bagi laki-laki atau suami. Ia adalah penolong yang berharga ${ }^{45}$, Penolong yang dapat dipercayai oleh suaminya, ${ }^{46}$

\footnotetext{
${ }^{41}$ John Piper, This Momentery Marriage, (Bandung: Pioner Jaya, 2012), 158

${ }^{42}$ Volkhard, Gerlinde Scheunemann, Hidup Sebelum dan Sesudah Nikah, (Batu: Dept Literatur YPPII), 14

${ }^{43}$ Yakub Susabda..., 45

${ }^{44}$ Ni Wayan Martha Manaransyah, Perempuan Bijak, (Batu: Dept Literatur YPPII, 2003), 4

${ }^{45}$ Band. Amsal 31:10

${ }^{46}$ Band. Amsal 31:11
} 
Penolong yang Rajin, kreatif dan terampil, ${ }^{47}$ penolong yang kuat ${ }^{48}$, penolong yang penuh perhatian, murah hati ${ }^{49}$, berhikmat, ${ }^{50}$ mahkota bagi suaminya. ${ }^{51}$

Istri yang memahami hakikatnya dan menjalankan fungsinya sebagai penolong bagi suaminya adalah istri yang takut akan Tuhan dan Istri yang takut akan Tuhan pasti berusaha menciptakan suasana bahagia dalam rumah tangganya. Itulah sebabnya dalam pernikahan kristen harus sama-sama beriman kepada Tuhan Yesus, karena jika istri bukan orang beriman kepada Kristus maka sudah tentu tidak mampu melaksanakan peranannya sebagai penolong bagi suaminya ataupun keluarganya dalam terang Tuhan.

\section{Ibu Bagi Anak-Anak}

Kehadiran seorang anak dalam keluarga adalah anugerah Tuhan, oleh karena itu seorang ibu dalam keluarga Kristen harus memberikan perhatian khusus bagi kehidupan anak-anaknya.Istri tidak hanya berperan sebagai penolong dalam hidup dan kemajuan karier suami, tetapi juga menentukan kemajuan anak anak, baik kemajuan dalam ilmu pengetahuan maupun kemajuan rohani anak-anak. Dalam kitab Amsal 1:8b, mengatakan "Hai anakku, dengarkanlah didikan ayahmu dan janganlah menyia-nyiakan ajaran ibumu", hal ini memberikan petunjuk bahwa seorang ibu adalah seorang pengajar dan pendidik bagi anak-anak. Tugas mengajar bukan hanya semata-mata oleh guru di sekolah namun juga tanggung jawab orang tua, khususnya ibu. ${ }^{52}$ Dan tidak hanya menyangkut pelajaran atau pekerjaan rumah anak-anak tetapi menyangkut pelajaran tentang hukum-hukum Tuhan juga.

Seorang ibu juga berperan sebagai pemelihara dan pengasuh anak-anaknya, (Amsal 31:23a), menyediakan makanan bagi anak-anaknya (Amsal 31:15a), mengawasi anak-anak (Amsal 31:27a). Ni wayan Martha Manaransyah mengatakan;

Anak-anak tidak cukup hanya diberi makan, minum serta dipenuhi segala kebutuhan jasmaninya.Mereka membutuhkan kehadiran diri ibunya sendiri. Mereka memerlukan perlindungan dan rasa aman. Rasa aman sedemikian pentingnya di dalam kehidupan anak karena menjadi dasar untuk perkembangan harga diri anak/ Ilmu Psikologi membuktikan bahwa seorang ibu memainkan peranan yang luar biasa pentingnya mengukir jiwa anak. ${ }^{53}$

Sebagai seorang ibu bagi anak-anak, ia juga berperan sebagai imam bagi anakanaknya, lebih lanjut Ni Wayan Martha mengatakan bahwa seorang ibu yang Tuhan percayakan anak-anak, tidak seharusnya frustasi, karena mereka sebenarnya tidak berjuang sendiri, tetapi bersama Tuhan, karena anak-anak adalah pinjaman dari Tuhan. Seorang ibu menjadi imam bagi anak-anaknya, membawa segala masalah dalam kehidupan anak-anaknya kepada Tuhan. Imam juga berarti perantara atau penyambung lidah dari Tuhan yakni menyampaikan kebenaran firman Tuhan dan kehendak Tuhan kepada anak-anak, sehingga hidup seorang ibu menjadi saluran

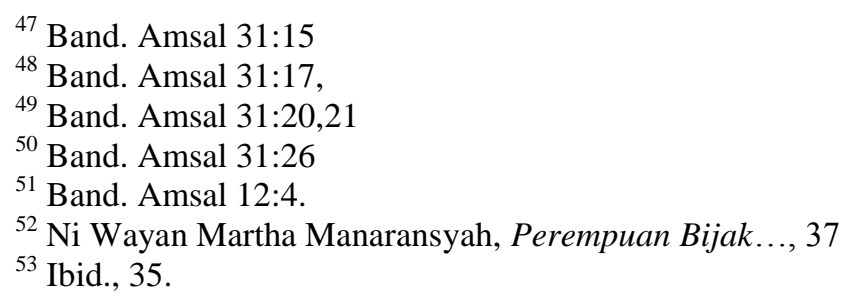


yakni saluran dalam tangan Tuhan. ${ }^{54}$ Oleh karena itu, seorang ibu dalam keluarga Kristen haruslah benar-benar seorang yang beriman sungguh-sungguh kepada Tuhan Yesus sehingga ia mampu menjalankan fungsi atau peranannya sesuai dengan terang Firman Tuhan.

\section{Pendoa Syafaat}

Istri juga berperan sebagai pendoa syafaat bagi keluarganya. Pendoa syafaat bagi suami dan anak-anaknya. Istri yang takut akan Tuhan berusaha menolong suami dan anak-anaknya untuk melakukan kehendak Tuhan. Dan salah satu hal yang dilakukannya adalah mendoakan suaminya atau keluarganya dengan setia. Doa seorang Istri bagi suaminya sangat penting karena melalui doa, suami dikuatkan, dimenangkan, diberkati, dilindungi serta dipakai Tuhan. ${ }^{55}$

Seorang istri harus sungguh-sungguh memahami bahwa Doa merupakan senjata yang ampuh dalam menanggung segala perkara yang mungkin terjadi dalam rumah tangganya. Oleh karena itu sebagai seorang istri, harus hidup dalam kebenaran. Sebab segala perkara dapat ditanggung di dalam doa, karena doa orang benar sangat besar kuasanya (Yak. 5:16b). Artinya bahwa melalui doa-doa yang dipanjatkan oleh istri kepada Tuhan akan menolong keluarganya (suami dan anakanaknya) untuk mampu menghadapi dan mendapatkan jalan keluar dari Tuhan atas pergumulan-pergumulan hidup yang diijinkan Tuhan uantuk mereka hadapi keluarganya.

\section{Pasangan Suami Istri Yang Tidak Seiman}

Untuk lebih memahami mengenai pasangan suami istri yang tidak seiman, maka di bawah ini akan diuraikan pengertian pasangan suami istri, faktor-faktor penyebab pasangan suami istri tidak seiman dan dampak-dampaknya.

\section{Pengertian Pasangan Suami Istri Tidak Seiman}

Adapun pengertian pasangan suami istri tidak seiman adalah pasangan suami istri yang sudah terikat dalam ikatan hukum pernikahan namun berbeda iman percayanya. Hidup sebagai pasangan dalam ikatan perkawinan namun salah satunya (suami atau istri) berbeda agamanya. Tidak satu kepercayaan atau tidak menyembah Allah yang sama, dapat disebut pasangan suami istri yang beda Agama.

Pernikahan pasangan suami istri yang berbeda iman disebut juga kawin campur. ${ }^{56}$ Nikah beda agama (perkawinan campuran) adalah perkawinan antara dua orang, pria dan wanita, yang tunduk pada hukum yang berlainan karena beda agama.

Dalam Perjanjian Lama diceritakan mengenai perkawinan yang tidak seiman (kawin campur). Perkawinan bagi bangsa Isarel didasarkan pada 'Perjanjian bangsa

\footnotetext{
${ }_{55}^{54} \mathrm{Ni}$ Wayan Martha Manaransyah, Perempuan Bijak..., 21

${ }^{55}$ Ibid., 21

${ }^{56}$ Kawin campur adalah Perkawinan di antara dua pihak yg berbeda agama, kebudayaan, golongan, atau suku bangsa (Band.https://www.kamusbesar.com/kawin-campur, diakses pada tanggal 11 maret 2018). maret 2018.

57 https://komarsuyut.wordpress.com/2013/12/08/nikah-beda-agama, diakses pada tanggal 11
} 
Isarel menjadi umat Tuhan (Kel. 6:6-7). Umat Tuhan menaati peraturan-peraturan Tuhan termaksud mengenai aturan perkawinan yang telah ditetapkan. Bangsa Israel hanya boleh melakukan perkawinan dengan bangsa Israel dan monogamy. Bangsa Isarel juga dimungkinkan boleh menikah dengan sanak keluarga sendiri, misalnya: Ishak mencari istri dari antara keluarga di Mesopotamia.

Pasangan suami atau istri tidak seiman dalam PL dan PB berarti pasangan di mana antara suami atau istri berbeda agama 'salah satu pasangan seorang penyembah berhala', atau bangsa-bangsa diluar Israel 'suku-suku dan budaya yang tidak percaya Tuhan Allah Israel,' yang juga disebut perkawinan campur. Pada masa Perjanjian Lama pernah terjadi pasangan suami istri yang tidak seiman, contohnya; perkawinan yang dilakukan oleh Yusuf mengawini Asnat orang Mesir (Kejadian 41:44-45), Musa mengawini Zipora orang Mediam (Kel. 2:21), Simson mengawini Delila orang Filistin (Hak 14:4), dan anak-anak dari Naomi (Kitab Rut).

Pasangan yang mengambil pasangannnya dari bangsa lain dan agama-agama diluar Isarel dengan alasan politik dilakukan oleh para raja contohnya; Saul, Daud, Salomo. DeVaux mengatakan "Para penguasa di Israel terlibat juga dengan perkawinan beda bangsa dan beda agama misalnya raja Daud, raja Ahab, raja Salomo, dengan alasan politik" ${ }^{, 58}$

Perkawinan yang dilakukan oleh bangsa Israel terhadap bangsa-bangsa lain tetaplah pelanggaran hukum-hukum Allah. Pelanggaran yang di lakukan bangsa Israel tersebut dalam pernikahan membuat bangsa Israel mengalami kerugian yaitu kehidupan iman dan keluarga menjadi hancur; bangsa Isarel yang memiliki pasangan tidak seiman meninggalkan Tuhan "ikut menyembah berhala' dan hancurnya masa depan keluarga dan kerajaan 'umat Tuhan' (Salomo, Ahab). Dalam Raja-Raja 11:11 menjelaskan keputusan-keputusan untuk kawin dengan beda agama dan bangsa membawa anggota lainnya 'umat Tuhan' ikut-ikutan menyembah berhala sehingga melakukan apa yang jahat dimata Tuhan dan dianggap melanggar perjanjian dengan Tuhan.

Peraturan dan perjanjian antara Allah dengan bangsa Israel tetap berlaku dalam PB untuk peraturan tidak memperbolehkan mengambil pasangan yang tidak seiman.Namun peraturan dan perjanjian itu juga dilanggar dengan berbagai alasan. Misalnya 1Petrus 3:1-7 Petrus memperhatikan bahwa di sana terjadi perkawinan campur karena orang-orang yang percaya Tuhan Yesus sebagai pendatang tersebar di Pontus, Asia Kecil, Kapodokia, dan Bitinia. Di Korintus juga terjadi pernikahan beda iman; kemungkinan karena hasil penginjilan Paulus salah satu pasangan menjadi percaya sedangkan pasangan lainnya belum, atau karena situasi sebagai pendatang dan lingkungan di Korintus yang juga tinggal orang-orang dari bangsa lain dan aliran-aliran sekte misalnya filsafat Stoa dan Snik, dualistisk. ${ }^{59}$

Peraturan yang sudah ditetapkan oleh Alkitab bagi orang-orang percaya yaitu; dilarang untuk menikah dengan pasangan yang tidak seiman, karena itu akan mengakibatkan krisis kerohanian dan persoalan-persoalan yang mengakibatkan kerugian bagi kedua belah pihak. Jika telah terjadi atau ada pasangan suami istri yang tidak seiman oleh karena faktor hasil penginjilan satu dari pasangan menjadi beriman, bagaimana mereka hidup telah dijelaskan dalam 1 Korintus 7:12-16.

\footnotetext{
${ }^{58}$ De Vaux, Marriage, (USA: MC.Grow-Hill, 1961), 31

${ }^{59}$ Ptitzner, Tafsiran atas surat I Korintus, (Jakarta:BPK Gunung Mulia, 1985), 189
} 


\section{Faktor-Faktor Penyebab Pasangan Suami Istri Tidak Seiman}

Untuk lebih memahami faktor yang menyebabkan pasangan suami istri tidak seiman akan dibagi dalam dua bagian faktor yaitu pertama, faktor internal dan kedua, faktor eksternal.

\section{Faktor Internal}

Faktor internal adalah faktor yang berasal dari dalam diri seseorang Dalam kaitannya dengan penyebab pasangan suami istri tidak seiman berarti faktor yang berasal dari dalam diri laki laki atau perempuan yang telah menjadi pasangan suami istri.

\section{Degradasi Iman (Lemah Iman)}

Faktor degradasi iman yang dimaksud disini adalah faktor tidak bertumbuh iman dalam Kristus atau kurangnya pemahaman tentang keberanan Allah yang sesungguhnya. Karena faktor ini maka membuat pria atau wanita memilih atau menentukan pasangannya tanpa memperhatikan apakah sesuai dengan kehendak Tuhan atau tidak.

Faktor degradasi iman menjadi salah satu penyebab pasangan dapat hidup sebagai pasangan suami yang tidak seiman, dimana sebelumnya pasangan tersebut sama-sama pasangan beriman namun karena kurangnya pemahaman kebenaran Alkitab, imannya menjadi lemah sehingga orang tersebut tinggalkan Kristus dan percaya kepada agama lain, namun pasangan tersebut tetap hidup sebagai pasangan suami istri.

\section{Terlanjur Cinta}

Terlanjur cinta adalah salah faktor penyebab pasangan dapat hidup dalam ikatan pernikahan pernikahan yang berbeda iman. Cinta adalah sebuah emosi dari kasih sayang yang kuat dan ketertarikan pribadi. Dalam konteks filosofi cinta merupakan sifat baik yang mewarisi semua kebaikan, perasaan belas kasih dan kasih sayang. Pendapat lainnya, cinta adalah sebuah aksi/kegiatan aktif yang dilakukan manusia terhadap objek lain, berupa pengorbanan diri, empati, perhatian, kasih sayang, membantu, menuruti perkataan, mengikuti, patuh, dan mau melakukan apa pun yang diinginkan objek tersebut. ${ }^{60}$ Jonar Situmorang mengatakan; cinta adalah emosi yang timbul antara satu dengan yang lainnya dengan maksud saling mengenal dan menyayangi dalam berbagai bentuk relasi dan wujud tertentu. ${ }^{61}$

Stephen Tong, dalam bukunya yang berjudul 'keluarga bahagia' mengatakan; Dari keindahan struktur masyarakat, Tuhan telah menciptakan manusia dengan sifat mutual yang ada pada setiap pribadi. Sifat mutual berarti potensi manusia untuk mengasihi dan dikasihi. Manusia bisa mencintai dan bisa dicintai. Manusia butuh penyaluran cinta dari dirinya, sebagai inisiator emosi. Tetapi manusia juga memerlukan penerimaan cinta untuk dirinya, sebagai penerima (receiver). ${ }^{62}$

Cinta sesungguhnya adalah anugerah Tuhan. Oleh karena itu harus dijalani dalam ketulusan, kejujuran dan dalam takut akan Tuhan. Namun ada juga pasangan

\footnotetext{
${ }^{60}$ https://id.wikipedia.org/wiki/Cinta, diakses pada tanggal 15 Februari 2017

${ }^{61}$ Jonar Situmorang, Berani Menikah, (Jogyakarta: Penerbit Andi, 2016), 169

${ }^{62}$ Stephen Tong, Keluarga Bahagia..., 25.
} 
yang salah mengartikan cinta, menganggap cintanya sebagai sebuah keharusan untuk melakukan hubungan fisik seperti aktifitas seksual. ${ }^{63}$ Bahkan menganggap cintanya sebagai sesuatu yang harus diteruskan ke jenjang pernikahan sekalipun salah satu diantaranya tidak seiman. Karena itu ia berusaha menghalalkan berbagai macam cara agar keinginannya tercapai sekalipun pasangannya tidak seiman dengan dia. Les dan Leslie Parrot mengatakan "cinta itu buta dan orang yang jatuh cinta tidak bisa melihat kebodohan-kebodohan yang mereka lakukan. ${ }^{64}$ Pria atau wanita yang beriman beranggapan bahwa saya dapat membawa pasangan saya kepada Kristus, sehingga memaksakan diri untuk menikah atau sebaliknya Pria atau wanita yang belum percaya Kristus mengalah untuk mengikuti pasangannya yang beriman kepada Kristus karena cintanya, dan tentunya hal ini menunjukkan bahwa motifasinya mengikut Kristus adalah salah, sehingga berjalannya waktu akhirnya salah satu pasangannya kembali kepada agamanya semula. Namun tetap menjadi pasangan suami istri (tidak berpisah).

Cinta merupakan dalih yang kuat seseorang mau menjalankan pernikahan beda agama. Cinta memang merupakan energi yang terkuat yang dapat mencelikkan sekaligus membutakan mata hati seseorang akan pribadi orang lain, sehingga dapat saja orang berdalih mengenai pernikahan beda agama karena "sudah terlanjur cinta". Di satu sisi, kalau tidak cinta, tidak mungkin pernikahan beda agama dapat terjalin, juga tidak mungkin berjalan langgeng dan harmonis. Inilah mengapa cinta merupakan dua sisi yang agak rumit dari pernikahan beda agama.

John Paper mengatakan "Pernikahan bukan hanya soal mempertahankan cinta. Ini soal memberitakan kebenaran melalui kehidupan kita.Ini soal memberikan gambaran yang benar tentang Yesus Kristus dan cara-Nya berhubungan dengan umat-Nya. Ini soal menunjukkan kemuliaan injil melalui kehidupan nyata" ${ }^{65} \mathrm{Jadi}$, seharusnya memilih pasangan hidup (menikah), hal utama yang harus diperhatikan adalah sisi spiritualnya, bukan hanya kekuatan saling mencintai diantara keduanya karena pernikahan adalah panggilan untuk menjadi saksi Kristus.

\section{Umur}

Faktor umur sudah cukup bisa menjadi alasan seseorang untuk cepat-cepat menikah. Sehingga seringkali seseorang yang sudah merasa cukup umur menikah, menuntut dirinya untuk menikah secepatnya. bahkan dipenuhi dengan kegelisahan, rasa takut karena umurnya sudah terlalu tua untuk menikah, akibatnya orang-orang yang memiliki konsep ini, bisa salah menentukan pasangan hidupnya. Peneliti pernah melayani seseorang yang sudah terlanjur menikah dengan pasangannya yang hanya karena faktor umur sudah tua, ia memilih menikah dengan orang yang sebenarnya ia tidak cintai, ia terpaksa mengorbankan imannya agar pernikahannya itu terjadi. Akhirnya mereka menjadi pasangan suami istri, namun ketika persoalan-persoalan baru mulai muncul dalam mengarungi rumah tangganya, penyesalan terjadi, yang pada akhirnya salah satu diantaranya harus kembali kepada iman dan kepercayaannya sebelumnya, ia tetap hidup dalam ikatan pernikahan itu namun sudah berbeda iman.

\footnotetext{
${ }^{63}$ Jonar Situmorang, Berani Menikah..., 170.

${ }^{64}$ Les dan Leslie Parrot, Relationships, (Batam: Gospel Press, 2001), 137

${ }^{65}$ John Paper..., 25
} 
Menikah bukan karena sudah cukup usia. Bukan waktu yang mendesak manusia untuk menikah tetapi menikah karena kehendak Allah.Bersatunya seorang laki-laki dan seorang Perempuan menjadi pasangan suami istri dalam pernikahan adalah panggilan Tuhan. Stephen Tong berkata; cepat-cepat menikah karena terdesak waktu (umur), itu sifat binatang bukan manusia. ${ }^{66}$

\section{Hasil Penginjilan}

Sebuah pasangan suami istri dapat hidup sebagai pasangan yang tidak seiman sebagai hasil penginjilan. Artinya sebelum mereka menikah baik suami maupun istri bukanlah Kristen atau dua-duanya belum percaya kepada Kristus. Namun pada perjalanan pernikahannya salah satunya bertobat dan percaya kepada Tuhan Kristus. Mereka tetap hidup sebagai pasangan suami istri tetapi berbeda iman atau agama. Hal ini sama seperti yang terjadi di Jemaat Korintus, dimana latar belakang orangorang percaya disana bukanlah Kristen namun oleh pelayanan Rasul Paulus mereka menjadi percaya kepada Kristus, tetapi karena pemahaman keberanan dalam perkawinan lemah sehingga banyak pasangan yang kembali kepada agamanya semula, namun tetap hidup sebagai pasangan suami istri (1 Korintus 7:12-16).

\section{Seks Sebelum Menikah}

Yang peneliti maksudkan dalam bagian ini adalah menikah karena alasan telah terlanjur berhubungan seks sebelum menikah sebagai pertanggunjawaban moral terhadap pasangannya. Laki laki atau perempuan dapat berdalih mengenai pernikahan beda agama karena "sudah terlanjur berhubungan seks, sementara seks bukanlah dasar penyatuan sebuah pasangan. Pernikahan yang didasarkan karena sudah terlanjur berhubungan seks hanya akan membawa kepada penderitaan hidup bahkan kematian kekal menjadi bagiannya jika tidak ada pertobatan.

Alkitab memberikan alasan pernikahan yang positif yaitu bahwa pernikahan merupakan rencana Allah dalam kehidupan manusia ciptaanNya. Suatu hubungan berdasarkan seks semata-mata mudah retak, namun hubungan yang dijalin bersama diseputar hal-hal Allah tak mudah patah. ${ }^{67}$ Lebih lanjut Norman L Geisler mengatakan bahwa;

"kita boleh saling mencintai, kita boleh memiliki upacara pernikahan yang dirahasiakan, dan kita boleh beranggapan kita akan saling berkomitmen untuk hidup namun kebenarannya adalah bahwa segala hal tersebut tidak membentuk hubungan perkawinan yang Alkitabiah. Perkawinan senantiasa merupakan hubungan perjanjian dengan Allah dan dihadapan manusia dan bukan untuk menggenapi peraturan Alkitabiah bagi perkawinan dan hubungan seksual adalah dosa". ${ }^{6}$

Jadi, Seks sebelum menikah, bukanlah dasar atau alasan bagi seorang laki-laki dan seorang perempuan untuk bersatu sebagai pasangan suami istri tetapi menikah karena panggilan Allah.

\footnotetext{
${ }^{66}$ Stephen Tong..., 22

${ }^{67}$ Norman L Geisler, Etika Kristen: Pilihan dan Isu Kontemporer, (Malang: Literatur SAAT,

${ }^{68}$ Ibid., 329
} 2010), 324-325. 


\section{Hamil Di Luar Nikah}

Hamil diluar nikah menjadi salah satu alasan bagi suatu pasangan mudi-mudi untuk menikah. Seseorang terpaksa menikahi pasangannya karena hamil. Jadi, faktor perbedaan iman bukanlah menjadi pertimbangan utama baginya tetapi karena hamil diluar nikah. Kehamilan diluar nikah adalah dosa dan membentuk keluarga karenanya sekalipun berbeda iman tidaklah sesuai dengan kebenaran Tuhan. Rasul Paulus katakan kepada Jemaat di korintus "Janganlah kamu menjadi pasangan yang tidak seimbang dengan orang-orang yang yang tak percaya, sebab persamaan apakah terdapat antara kebenaran dan kedurhakaan? Atau bagaimanakah terang dapat bersatu dengan gelap. ${ }^{69}$

\section{Faktor Eksternal}

Pada bagian ini peneliti akan membahas faktor-faktor eksternal yang dapat menyebabkan pasangan dapat hidup sebagai pasangan suami istri yang berbeda iman.

\section{Faktor Perjodohan}

Faktor perjodohan bisa menjadi alasan seseorang untuk menikah. Perjodohan ini bisa dilakukan oleh orangtua atau keluarga besar. Jika orangtua yang menjodohkan maka banyak alasannya, contohnya adalah supaya bisa cepat menggendong cucu. Stephen tong mengatakan; bukan demi melayani orangtua yang sedemikian ingin menggondong cucu maka cepat-cepat menikah. Setiap orang yang mau menikah harus mempunyai pengertian makna pernikahan yang dikaitkan dengan mencari Allah, sehingga dapat mengusai emosi dan nafsu sendiri. Kalau tidak, saudara tidak berhak menikah. ${ }^{70}$ Contoh lain untuk meningkatkan martarbat keluarga, kelebihan yang dinilai dari orang yang akan dijodohkan kepada anaknya (misalnya pangkat tinggi dalam pekerjaan)

Sekalipun demikian, terbentuknya sebuah pasangan suami istri seringkali terjadi karena perjodohan yang direkayasa orang tua atau keluarga besar ${ }^{71}$ kadang tanpa memikirkan nilai-nilai agama yang dianut, sehingga pernikahan terjadi secara terpaksa, sekalipun berbeda iman. Orangtua memiliki persepsi bahwa menikahkan anak sebagai pembuktian diri dalam membesarkan anak. Ada tekanan sosial yang dirasakan orang tua jika anak belum menikah mereka merasa gagal sebagai orang tua. Dilihat dari sisi yang dijodohkan, mereka menyetujui perjodohan supaya orang tua dan keluarga bahagia karena punya anak yang berbakti.

\section{Faktor Ekonomi}

Persoalan ekonomi terkadang juga menjadi penentu dalam memilih pasangan hidup, sehingga kadang persoalan agama terabaikan demi kepentingan ekonom. Menikah adalah pencapaian hidup paling mudah bagi orang miskin; disebabkan 'faktor ekonomi / finansial' dan berpendidikan rendah' yang sulit dalam menemukan

${ }^{69} 2$ Korintus 6:14

${ }^{70}$ Stephen Tong..., 23

${ }^{71}$ Wawancara via telp dengan CPL - 01 tangal 29 Mei 2018 jam 15.00 WIB, seorang ibu menceritakan dia menikah dengan pasangan tidak seiman karena dijodohkan oleh abang kandungnya. Waktu itu setelah tamat sekolah ibu ini dipanggil abangnya untuk ke Palembang, ternyata sampai di sana sudah beredar undangan pernikahan. Abangnya menawarkan dan memaksakan supaya ibu ini mau terima karena orangnya baik, pekerjaannya dan jabatannya juga bagus dan teman baik abangnya. 
paangan hidup. Banyak orang tua memaksakan atau mengkompromikan bahkan menghalalkan segala cara supaya anaknya bisa menikah 'meskipun beda agama' untuk meringankan beban dan biaya hidup mereka. ${ }^{72}$

Persoalan ekonomi terkadang menjadi penentu dalam memilih pasangan hidup sehingga kadang persoalan agama terabaikan demi kepentingan ekonomi.

\section{Faktor Pendidikan}

Pendidikan bisa menjadi penentu bagi pasangan menikah meskipun tidak seiman. Penyebabnya pola pikir pendidikan; pendidikan rendah ataupun pendidikan tinggi menjadi penyebab pernikahan tidak seiman. Pendidikan yang dilakukan dalam keluarga besar jika tidak memegang prinsip agama (kebebasan untuk menentukan agama masing-masing) akan memudahkan anak-anak untukku memilih pasangan sesuai keinginannya tanpa mempertimbangkan agama.

\section{Faktor Budaya}

RC.Sproul mengatakan; pernikahan bukanlah hasil dari perkembangan kebudayaan manusia. Institusi pernikahan ditetapkan seiring dengan penciptaan itu.Sekalipun demikian pernikahan seringkali terjadi karena tuntutan budaya.Dalam hal menentukan pasangan hidup terkadang diharuskan untuk menikah dengan sesama sukunya, walaupun terkadang resikonya tidaklah seiman.Kenyataan di Indonesia masyarakat sangat heterogen, multicultural dan multiagama yang terdiri dari berbagai macam agama, suku dan budaya, sehingga pemikiran antar budaya dan agama menjadi toleransi dan keniscayaan (terbuka dan menerima). Demikian juga pada masa Era globalisasi ini menyebabkan terbukanya perkawinan antar bangsa, suku, dan agama. Keadaan dan kondisi di suatu daerah misalkan akan turut mempengaruhi pengaturan hukum perkawinan di daerah tersebut.

Menurut pengamatan penulis, penyebab pasangan menikah beda agama dalam kebudayaan dan suku tertentu, dikarenakan kehadiran pendatang dan minoritas pemeluk agama yang seiman di tempat yang mayoritas berbeda agama. Akibatnya yang minoritas mengambil yang mayoritas dan menikah beda agama. Agama masih menjadi salah satu factor penghambat, banyak pasangan yang kemudian putus oleh perbedaan agama. Yang tetap bersikukuh, dihadapkan pada dua pilihan yaitu nikah agama atau salah satu mengalah mengikuti agama pasangannya.

\section{Dampak Buruk Pasangan Suami Istri Yang tidak Seiman}

Salah satu tujuan pernikahan Kristen adalah bagaimana pasangan suami istri tersebut menikmati kedamaian, sukacita, kehormanisan relasi dan kesatuan dalam melakukan kehendak Tuhan di dalam keluarganya. Tujuan ini terancam tercapai dalam kehidupan pasangan suami istri yang tidak seiman. Ada banyak dampak buruk yang terjadi dalam kehidupan keluarga pasangan yang tidak seiman. Berikut akan di uraikan dampak buruk bagi pasangan suami istri yang tidak seiman.

\footnotetext{
${ }^{72}$ Kisah seorang jemaat sebelum menikah Kristen, pacaran dengan beda agama (Islam), Orang tua menawarkan jika menikah dengan anaknya dan masuk agama Islam maka akan diberi satu unit rumah. Via telepon tanggal 29 Mei 2018 jam 16.00 WIB
} 


\section{Spiritual}

Bagi pasangan yang beda agama atau tidak seiman, pasti mengalami ketidaknyaman atau ketidakharmonisan dalam melaksanakan keyakinan agamanya masing-masing karena menganggap agamanya paling benar. Naomi Schaefer Riley menjelaskan" pasangan yang tidak seiman kurang bahagia dan kemungkinan terjadi perceraian. Ada juga kecendrungan untuk mengalami kemunduran dalam pertumbuhan rohani". ${ }^{73}$ Pertumbuhan rohani yang dipengaruhi oleh ketidakyamanan dan menjaga perasaan pasangan berakibat kompromi (iman pribadi diabaikan) bahkan bisa dikatakan hidup dalam keberdosaan (tidak menjalankan keyakinannya dengan sepenuh hati kepada Tuhan Yesus). Seperti cerita Salomo yang mencondongkanhati kepada allah-allah yang disembah istrinya dan tidak sepenuh hati beribadah kepada Allah (I Raja-Raja 11:4-6).

Bagi pasangan yang tidak seiman dalam menghadapi masalah rohani, imannya tidak mudah untuk bertumbuh karena tidak ada dukungan dari pasangannya yang tidak beriman. Tidak adanya persekutuan dalam rumah tangga 'mezbah keluarga', suami atau istri yang beriman tidak berusaha membawa anggota keluarganya untuk percaya Yesus, tidak mendapatkan dukungan sepenuhnya dari pasangannya yang tidak beriman untuk melaksanakan tuntutan imannya, termasuk kegereja. Kalaupun sampai sekarang mereka masih menghabiskan hidup bersama dengan orang yang menurut agama 'dianggap keliru, bersalah' karena masih menjaga diri untuk tidak saling menyakitkan.

Pasangan suami istri jika ditinjau menurut hukum perkawinan di Indonesia; pernikahan diakui jika pasangan yang pernikahannya telah di sahkan dan dilaksanakan menurut hukum masing-masing agamanya atau kepercayaannya. ${ }^{74}$ Setiap agama punya pandangan dan pengajaran mengenai pasangan yang tidak seiman, misalnya: agama islam, jika menikah dengan beda agama disebut musyrik, ${ }^{75}$ ajaran Katolik memandang bahwa perkawinan diluar agama Katolik adalah bentuk perkawinan yang tidak ideal $^{76}$ dan tidak sah karena perkawinan dimasukkan kedalam doktrin sakramen yaitu tanda kehadiran Allah, dalam ajaran Kristen pernikahan hanya diperbolehkan bagi pasangan yang tidak seiman ${ }^{77}$ jika dengan agama lain Allah pasti murka (berarti tidak diperbolehkan). Disinilah keberatan-keberatan ajaran agama akan terus menghantui hubungan antarsuami, yang mengakibatkan kesulitan untuk bersatu secara rohani bahkan berdampak kepada anak (anak bisa dinyatakan sebagai anak cemar, tidak kudus, tidak diakui).

\footnotetext{
${ }^{73}$ http:www.mapsofword.com/poll/images/dointerfaith-marrieges-workinfographic .jpg. diakses pada 2 Mei 2018

74 Di Indonesia Undang-undang pernikahan atau juga disebut perkawinan telah di atur sebagaimana tertulis dalam Undang-Undang Perkawinan No. 1 tahun 1974 yang mengatakan: Pernikahan adalah ikatan batin antara seorang pria dengan seorang wanita sebagai suami istri dengan tujuan membentuk keluarga yang bahagia dan kekal berdasarkan ketuhanan Yang Maha Esa. Untuk laki-laki minimal sudah berusia 19 tahun dan untuk perempuan harus sudah berusia minimal 16 tahun. Jika menikah di bawah usia 21 tahun harus disertai dengan ijin kedua atau salah satu orang tua yang ditunjukan sebagai wali.

${ }^{75}$ Tertulisdalam surat Al-Baqarah 2:21)

${ }^{76}$ Ada hukum yang disebutKanon, dikenakkanKanon 1124 dan 1086

${ }^{77}$ Larangan yang tertulis dalam Ulangan 7:3-4
} 
Pendidikan agama dalam keluarga pasangan yang tidak seiman menjadi terhambat karena saling menjaga dan menghormati untuk menerapkan agama siapa yang diajarkan kepada anak-anak karena terikat perjanjian ${ }^{78}$; sedangkan bagi orang beriman, nilai-nilai pendidikan seharusnya diajarkan kepada anak (band Ulangan 6:6-8), supaya anak bertumbuh dalam kerohanian yang menuntun kehidupannya bagi masa depannya dalam hal tentang keyakinannya 'agamanya' (Hal ini orang tua beriman mengantar anaknya untuk melakukan Pengakuan Iman dengan 'Baptisan').

Kehidupan Pasangan suami istri yang tidak seiman juga mempengaruhi kehidupan rohani anak-anak mereka. Ada pasangan yang berbeda agama memberikan kebebasan kepada anak untuk memilih sendiri agama yang dianutnya tetapi tidak sedikit bahkan pada umumnya orang tua memberikan tekanan kepada anak anaknya agar memeluk agama yang dianutnya (sedangkan anak tidak mau). Misalnya; bila satu pihak sebagai orang tua beragama Kristen maka kemungkinan besar kecenderungannya adalah mendorong anak anaknya kepada agama Kristen, demikian juga sebaliknya dari pihak lain. Bagi suami istri yang memberikan pilihan agama pada sianak, besar kemungkinan anak akan menjadi korban mereka, sulit memilih pada agama siapa yang diikutinya dari kedua orangtua. Perasaan rasa bersalah jika memilih salah satu iman yang dianut oleh orang tuanya, mereka tertekan dan kemungkinan mereka bertumbuh menjadi pribadi yang tidak mau mengenal Tuhan secara baik.

\section{Dampak Psikologi}

Secara psikologis, perkawinan yang didasarkan pada pemenuhan biologis dan materi semata (faktor penyebab pasangan menikah dengan tidakseiman) tidak akan mendapat kebahagian. Perbedaan agama dalam perkawinan dapat menimbulkan tekanan psikologis berupa konflik kejiwaan, yang padagilirannya mengakibatkan disfungsi perkawinan itu sendiri. Jika terjadi konflik perbedaan agama yang tidak dapat diselesaikan, suami istri kemungkinan tidak akan mengamalkan ajaran agama yang dianutnya, tetapi memilih pola hidup sekuler. Pola sekuler akan menimbulkan konflik baru yang sulit diatasi, dan dapat menjurus kepada konflik keluarga. Selain itu juga terjadi 'toleransi' yaitu pendangkalan keimaman, yang menimbulkan depresi akibat bersalah dan berdosa dan perkembangan anak menjadi terganggu (apakah ia memilih ayahnya atau ibunya). ${ }^{79}$

Selain itu rasa tidak nyaman dalam hidup bersama dengan beda iman menimbulkan konflik-konflik dan ketegangan serta tidak percaya lagi, misalnya; salah satu pasangannya menjalankan ajaran agamanya dan tidak sesuai keinginan pasangannya menimbulkan potensi anggapan yang muncul dari pasangan bahwa ada upaya lain dibalik tindakan pasangannya tersebut. Atau berpikir 'jangan-jangan pasangannya akan berusaha menarik dirinya terhadap agamanya.

\footnotetext{
${ }^{78}$ Wawancara kepada seorang anak yang masih belum menentukkan agama siapa yang diikuti karena menjaga perasaan kedua orangtuanya walaupun sekarang anak tersebut menjalankan agama Kristen mengikuti mamanya, Ada 4 bersaudara, 1 orang sudah dibaptis, 1 orang anak kadang mengaku Kristen karena mama tapi kadang mengaku Islam ikut papa, 1 orang yang setia mengikuti agama Kristen tapi belum dibaptis, dan dirinya. Semua bersaudara sudah kuliah dan bekerja. Usia Pemuda dewasa. Tanggal 15 April 2018.

${ }^{79}$ DadangHawari, Ilmu Kedokteraan Jiwa dan kesehatan Jiwa, (Yogyakarta: Dana Bhakti Prima Yasa, 1997), 207-209
} 


\section{Dampak Sosial}

Tidak hanya rentan mengalami konflik, pernikahan beda agama juga dalam pandangan masyarakatan sosial belum' sepenuhnnya 'bisa menerima pernikahan pasangan berbeda keyakinan. Dalam Legalitas hukum, pernikahan beda agama belum disahkan. Jika membutuhkan catatan sipil, akte kelahiran, maka salah satu pasangan sepakat bersama untuk menentukan pernikahan mereka memakai agama apa, baru disahkan.

Dampak yang dialami pasangan tidak seiman bisa menjadi seorang yang mengasingkan diri atau menghindar dari lingkungan masyarakat, misalnya kesulitan rumah dipakai untuk ibadah, karena malu terhadap tetangga, ${ }^{80}$

Dampak lain juga mempengaruhi dilingkungan kerja dan tempat tinggal, misalnya kasus yang dialami oleh seorang ibu; Ibu ini beragama Kristen suami beragama Islam, sewaktu suaminya dimasukkan kedalam kenaikan pangkat dalam sebuah perusahaan suaminya bekerja, Manager mendatangi kerumah untuk memberitahu kesulitan dalam kenaikan pangkat karena perbedaan agama. Di lingkungan tempat kerja dan lingkungan juga menjadi pembicaraan 'dipandang sebelah mata'. 81

\section{Relasi Dalam Keluarga}

Sewaktu berdialog dengan pasangan yang beda iman, pasangan bisa saja tenang dengan mengatakan perbedaan iman bagi mereka tidaklah bermasalah. Tapi jika melibatkan keluarga besar, disinilah akan terlihat dampak yang dialami oleh pasangan yang tidak seiman dengan keluarga besar kedua belah pihak. Karena pernikahan bukan hanya mempersatukan pasangan tapi mempersatukan juga kedua belah pihak keluarga. Sebab itu tidak mudah bagi pasangan untuk mengajak pasangannya pindah kepada agamanya karena pertimbangan keluarga besar.

Konsekuensi jika terjadi perpindahan dari pasangan yang tidak seiman ini akan dimusuhi atau dijauhi keluarga yang terambil keyakinannya dengan mereka. Karena banyak orang tua kedua pihak pasangan itu tidak akan pernah ikhlas atau terima jika anaknya berpindah keyakinan, tetap akan menerima jika menantunya memiliki agama yang sama. Untuk pasangan suami istri yang tidak seiman konflik dari dampak yang dihadapi yaitu; saling menyalahkan, ancaman perceraian, pisah ranjang (ada selingkuh), dan hubungan sex menjadi tidak dinikmati sebagai anugerah Tuhan karena dianggap tidak suci. Sedangkan bagi Anak-anak kehilangan identitas diri, kebingungan menentukan keyakinan agama, minder dengan keluarga dari Lingkungan yang seiman, dan Mempersalahkan Orang tua yang tidak seiman, dan ketakutan dalam menentukan pilihan untuk pasangannya.

${ }^{80}$ Ada jemaat yang pernah peneliti layani suami Kristen dan istri Islam; mereka sepakat untuk menjaga dan tidak mengijinkan rumah dipakai untuk ibadah apa pun. Akibatnya ketika meninggal suami keluarga besar menolak untuk mayat suami di bawa kerumah sebelum dimakamkan ditempat peristrahatan terakhirnya.

${ }^{81}$ Wawancara dengan Ibu Dedi Panggabean, tanggal 29 April 2018. 


\section{PASANGAN SUAMI ISTRI TIDAK SEIMAN BERDASARKAN 1 KORINTUS 7:12-16}

Untuk lebih memahami bagian ini, maka akan diuraikan Analisa teks 1 Korintus 7:12-16.

\section{Analisa Teks 1Korintus 7:12-16}

Pada bagian analisa teks 1 Korintus 7:12-16, penulis membagi dalam 3 bagian untuk menjelaskan apa yang disampaikan Rasul Paulus dalam membimbing jemaat Korintus yang sedang mengalami persoalan Pernikahan, Moffat memulai penjelasannya mengenai 1 Korintus 7:12-16 dengan memberikan pernyataan keras bahwa, untuk masalah pernikahan dimana kedapatan seseorang mempunyai pasangan yang berbeda agama, maka seharusnya keputusan berada di tangan mereka sendiri. Ini tentu memberikan reaksi keras terhadap beberapa agama yang melarang pernikahan campuran. ${ }^{82}$

Dalam tafsiran Wayclife mengatakan bagaimana dengan pernikahan dimana salah satu pihak adalah Kristen? Hukum Yahudi mengharuskan penyingkiran orang yang tidak percaya (Ezr.9:1-10:44). ${ }^{83}$ Pandangan awal untuk pernikahan adalah "suci dan kudus". Pernikahan memang suci dan kudus, namun pandangan ini pun berakar dari pandangan bahwa orang Yahudi adalah orang suci dan kudus, dan kemudian bergeser ke dalam pandangan bahwa orang Kristen sajalah yang suci dan kudus sedangkan orang yang diluar Kristus adalah orang-orang cemar. Ini tentu memberikan tekanan dalam pandangan Paulus bahwa ada orang-orang kudus yaitu orang beriman dan ada orang-orang yang tidak beriman dan menimbulkan tingkatan konflik dalam hubungan keluarga dari pasangan yang berbeda agama. ${ }^{84}$

Kekudusan ataupun kecemaran dari pasangan yang melakukan nikah beda iman tidak hanya dimiliki sendiri oleh mereka, namun bisa diturunkan untuk anak mereka. Ini merupakan konsep "kekudusan" anak yang baru lahir dari seorang ibu yang di anggap pada zaman perjanjian baru adalah orang yang tidak beriman. Menurut Calvin's Commentary seorang anak yang lahir dari rahim orang percaya adalah anak-anak suci di dalam gereja, sama seperti pandangan Paulus dalam surat Roma bahwa kita terlahir sebagai anak-anak yang suci. Sedangkan Menurut Wycliffe, dalam bagian 1 Korintus 12-16 bukanlah peraturan akan pernikahan yang akan terjadi, melainkan nasihat Paulus kepada Pernikahan yang dulu dilakukan bagi sepasang manusia yang tidak beriman kemudian salah satu dari mereka menjadi Kristen dan yang lain tetap berpegang teguh pada kepercayaan mereka yang lama. Hal ini tentu akan memberikan sumbangan penting dalam memahami apa yang dikatakan Paulus dalam 1 Korintus 7:12-16.

${ }^{82}$ Conzelman: A Commentary On First Epistle To The Corinthians dalam walanghening.blogspot.com/2012/04/pernikahan-beda-agama-1-korintus-712-16.html, diakses pada 15 Mei 2018

${ }^{83}$ Charless F. Pfeiffer \& Everett. Harrison, Tafsiran Alkitab Waycliff..., 620

${ }^{84}$ Conzelman: A Commentary On First Epistle To The Corinthians dalam walanghening.blogspot.com/2012/04/pernikahan-beda-agama-1-korintus-712-16.html, diakses pada 15 Mei 2018

${ }^{85}$ Conzelman: A Commentary On First Epistle To The Corinthians dalam walanghening.blogspot.com/2012/04/pernikahan-beda-agama-1-korintus-712-16.html, diakses pada 15 Mei 2018. 
Menurut pandangan tersebut, penekanan utama dalam pemberitaan Paulus dalam bagian Alkitab ini adalah bagaimana seorang yang beriman mempertahankan pernikahannya dengan seorang yang tidak beriman. Secara ringkas ada 3 alasan yaitu; 1) seorang beriman tidak boleh menceraikan pasangannya yang tidak percaya kecuali jika pasangan tersebut meminta cerai, 2) anak-anak dari orang tua yang merupakan pasangan tidak seiman adalah anak-anak yang kudus. 3) Tuhan menghendaki orang beriman hidup dalam perdamaian di dalam tersirat tujuan pernikahan beda agama terdapat misi penyelamatan, yaitu dapat mempertahankan pernikahan dan menyelamatkan pasangannya.

Dalam 1 Korintus 7:12-16, Paulus hendak menyampaikan beberapa hal menyangkut pernikahan. Hal-hal tersebut bukanlah menyangkut tata cara/tradisi saja, melainkan perubahan paradigma berdasarkan pemikiran Paulus. Di dalam beberapa pernyataan Paulus mengungkapkan dasar dari perkawinan adalah "keinginan" untuk dipersatukan dalam ikatan pernikahan. Untuk itu percerian akan dimulai dengan "keinginan" untuk berpisah, dan sebagai orang yang beriman kita tidak bisa melawan keinginan tersebut, jika pasangan lain ingin bercerai (ay. 12). Paulus sendiri tidak bisa menjelaskan bagaimana dasar dari sebuah pernikahan adalah cinta karena ia sendiri adalah orang yang memilih untuk selibat, bahkan ia sempat mengajak jemaat untuk tidak kawin (ay. 1), namun bukan berarti ia tidak bisa menasehati orang-orang yang baru saja percaya kepada Kristus dalam pernikahan mereka. ${ }^{86}$

Pernyataan Paulus dalam 1 Korintus 7:12-16 merupakan sebuah proklamasi terhadap pandangan/paradigma baru. Semula, di dalam Yudaisme, konsep haram dan halal sangatlah kuat. Sesuatu yang haram bisa membuat sesuatu yang suci dan kudus ternoda, untuk itu yang suci tidak bisa didekati atau berhubungan dengan sesuatu yang haram karena yang suci dan kudus akan tercemar. Untuk masalah pernikahan hukum Yahudi mengharuskan untuk menyingkirkan orang yang tidak percaya (Ezr. 9:1-10:44). Sedangkan di dalam Perjanjian Baru, khususnya pendapat Paulus di dalam 1 Korintus 7:12-16 mereduksi pemikiran tersebut. Hal ini bisa terlihat pada ayat 14 dimana seorang istri yang beriman bisa menguduskan seorang suami yang tidak beriman. Tanpa menghilangkan paradigma awal, Paulus menegaskan bahwa: bukan hanya yang cemar dapat mempengaruhi yang suci, tapi juga yang suci dapat mempengaruhi yang cemar. Ini merupakan sebuah proklamasi terhadap pemikiran jemaat Kristen mula-mula oleh Paulus yang tidak menikah.

Berdasarkan pemikiran Paulus yang terdapat dalam 1 Korintus 7:12-16 terdapat gambaran misi penyelamatan dalam sebuah pernikahan. Misi penyelamatan ini bersifat terbuka terhadap siapa saja tanpa memaksakan kehendak. Misi penyelamatan ini dilakukan karena sudah terjadi pereduksian terhadap cara pandang yang kudus dan cemar, sehingga misi penyelamatan tidak dipandang sebagai suatu bentuk ekspansi kekristenan terhadap agama lain didalam sebuah keluarga berlatar belakang pernikahan beda agama. Itu berarti ada berbagai alasan mengapa Paulus tidak menyetujui adanya perceraian dalam sebuah keluarga yang sudah "terlanjur" menikah dan berbeda agama. Selain penyelamatan, alasan yang lain yaitu: Cinta,

86 walanghening.blogspot.com/2012/04/pernikahan-beda-agama-1-korintus-712-16.html, diakses pada tanggal 13 mei 2018 
sebagai sesuatu yang ultimate dan sacral sehingga tidak bisa ditiadakan oleh hasil konstruksi manusia lewat agama-agama. ${ }^{87}$

Ada pun pembagian yang diteliti untuk memahami teks I Korintus 7:12-16 adalah sebagai berikut:

\section{Ada Pasangan Suami Istri Yang Tidak Seiman}

Dalam analisa teks ini, maka diketahui bahwa di jemaat Korintus 'Ada pasangan yang tidak seiman' terdapat dari kalimat 'Kalau ada seorang saudara (suami) beristrikan seorang yang tidak beriman dan perempuan itu mau hidup bersama-sama dengan dia, janganlah saudara itu menceraikan dia" (ayat 12), Dan "kalau ada seorang istri yang tidak beriman dan laki-laki itu mau hidup bersamasama dengan dia, janganlah ia menceraikannya" (Ayat 13), "Kalau ada orang yang tidak beriman mau bercerai..." (ayat 15). Terjemahan Yunani ayat 12b “..., eï $\tau 1 \varsigma$

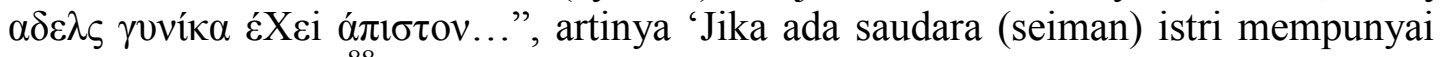
yang tidak percaya., ${ }^{88}$

Menurut Paul Ellingworth kata "Kalau Ada" adalah Keadaan yang dibicarakan oleh Paulus di ayat 12-13 dan 14-15 (seperti ayat 9), mungkin sekali memang terjadi dalam jemaat Korintus. Kalau memang demikian, maka kata-kata kalau ada berarti 'dalam hal', dan bagian ini dapat diterjemahkan 'seorang saudara Kristen' (kata saudara berarti orang Kristen) yang mempunyai istri bukan Kristen." ${ }^{\text {" Ka }}$ Kata kalau ada bukan menunjuk kepada Paulus tetapi kepada kata 'saudara' maksud saudara orang yang sudah percaya Kritus yang sudah menikah dengan tidak seiman.

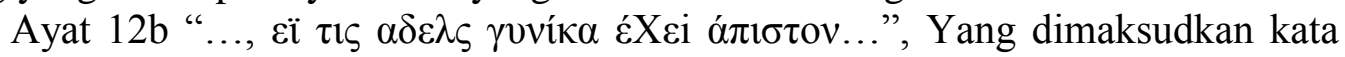
'tidak seiman' dalam teks Yunani mengunakan kata ' $\alpha \pi i \sigma \tau o v '$ (apiston) dipakai 23x, adalah kata sifat dari attributive yang memberi sifat akusatif tunggal yaitu 'yang tidak dapat dipercayai atau mustahil', 'yang tidak percaya' atau 'yang tidak beriman'. 90 Tidak percaya kepada Tuhan Yesus berarti tidak beriman. Dalam terjemahan NKJV dipakai kata 'not believe' tidak percaya. 'the unbelieving' ketidak percayaan, 'the unbeliever' orang yang tidak percaya. Terjemahan BSD kata yang menunjuk ke suami atau istri yang tidak seiman yaitu 'yang bukan Kristen', 'yang belum percaya Kristus', 'orang yang bukan Kristen'. Terjemahan FAYH menunjuk kepada bukan Kristen, TSI menterjemahkan 'yang belum percaya'. ${ }^{91}$ Pemakaian kata ini dapat diartikan kepada yang tidak percaya Kristus dan bisa dikatakan belum percaya tetapi kemungkinan bisa jadi percaya karena pernikahan dengan yang sudah percaya Tuhan Yesus.

\footnotetext{
${ }^{87}$ Conzelman: A Commentary On First Epistle To The Corinthians dalam walanghening.blogspot.com/2012/04/pernikahan-beda-agama-1-korintus-712-16.html, diakses pada tanggal 13 Mei 2018

${ }^{88}$ Hasan Sutanto, Perjanjian Baru Interlinear Yunani - Indonesia dan Konkordansi Perjanjian BAru, (Jakarta: LAI, 2002), 95

${ }^{89}$ Paul Ellingworth, Surat Paulus yang Pertama Kepada Jemaat Di Korintus, (Jakarta: LAI, 2010), 174

${ }^{90}$ Hasan Sutanto, Perjanjian Baru Interlinear Yunani - Indonesia dan Konkordansi Perjanjian Baru..., 95

____ Alkitab Elektronik
} 
Dengan demikian telah terjadi dan diketahui oleh jemaat Korintus dan Rasul Paulus bahwa di anggota jemaat Korintus ditemukan ada pasangan yang tidak seiman.

\section{Sikap Suami Atau Istri Beriman Bagi Pasangannya Yang Tidak Beriman}

Dalam I Korintus 7:12-13, Paulus menyampaikan suatu situasi yang yang belum muncul selama pelayanan Kristus di Palestina. Bagaimana mengenai pernikahan campuran (dalam dunia orang bukan Yahudi)? Dengan ini Injil telah tiba kepada bangsa-bangsa bukan Yahudi, dan terkadang salah satu dari pasangan kekasih telah beralih keyakinan sedangkan yang lainnya belum. Yesus belum berbicara kejadian dalam topik ini sewaktu Ia pelayanan di dalam dunia. Karena itu Paulus menulis, "Kepada orang-orang lain (orang-orang lain yakni orang percaya yang bukan Yahudi yang telah menikah dengan yang belum percaya) aku katakan, bukan Tuhan Yesus" (12). Memberikan pengertian bahwa Paulus menyadari bahwa dirinya bukan Tuhan tetapi ia memiliki pemahaman yang Tuhan (Yesus Kristus) miliki untuk diutarakan dalam menjawab persoalan pernikahan beda agama ini ayat 12 "kepada orang-orang lain aku, bukan Tuhan katakan...". Paull Ellingwort mengatakan Kata-kata ini menunjukkan bahwa keadaan yang sedang dialami jemaat Korintus ini belum pernah dibicarakan atau dibahas dalam ajaran Tuhan Yesus. Karena itulah Paulus menyebutkan bahwa nasehat di ayat ini hingga ayat 16 berasal dari dia sendiri, dan bukan dikutipnya dari ajaran Tuhan Yesus. ${ }^{92}$

Paulus tetap mengutip dan mengacu pada ajaran dan pengajaran Kristus. 3 kutipan dari Tuhan Yesus yang diangkat Paulus mengenai pernikahan dan perceraian, (I Korintus 7: 1-11) yaitu: mengambil salah satu dari ketiga catatan Injil: "Tetapi Aku berkata kepadamu: Setiap orang yang menceraikan isterinya kecuali karena zinah, ia menjadikan isterinya berzinah; dan siapa yang kawin dengan perempuan yang diceraikan, ia berbuat zinah." (Mat. 5:32). "Lalu kata-Nya kepada mereka: "Barangsiapa menceraikan isterinya lalu kawin dengan perempuan lain, ia hidup dalam perzinahan terhadap isterinya itu. Dan jika si isteri menceraikan suaminya dan kawin dengan laki-laki lain, ia berbuat zinah." (Mark. 10:11-12). "Setiap orang yang menceraikan isterinya, lalu kawin dengan perempuan lain, ia berbuat zinah; dan barangsiapa kawin dengan perempuan yang diceraikan suaminya, ia berbuat zinah." (Luk. 16:18).

Paulus meringkaskan ajaran-ajaran Kristus yang disampaikan ialah: Pertama, jangan bercerai: "seorang isteri tidak boleh menceraikan suaminya... Dan seorang suami tidak boleh menceraikan isterinya." (1 Kor. 7:10-11). Kedua, bagaimana jika pendampingmu meninggalkan dan menceraikannya (atas dasar percabulan yang alkitabiah [Mat. 5:32] atau sebaliknya)? Firman Allah memberikan anda 2 pilihan: baik "tetap tidak menikah" atau "didamaikan kembali" dengan suami atau istri karena masih "satu daging". Kitab Suci yang sakral tidak mengizinkan pilihan ketiga. "tetapi jikalau ia bercerai" atau "tetap hidup tanpa suami" atau "berdamai dengan suaminya" (11). Pernikahan lagi ketika pendampingnya masih hidup bukanlah satu pilihan. $^{93}$

92 Paull Ellingwort, Howard Hatton, Surat Paulus Yang Pertama Kepada Jemaat di Korintus..., 173

${ }^{93}$ www.sarapanpagi.org > BELAJAR ALKITAB > Alkitab > Ucapan Paulus yang Sulit 
Oleh karena alasan diatas, dalam memahami konsep berpikir ini, Paulus menyampaikan pengajarannya yang tidak menyimpang dengan ajaran Tuhan Yesus meskipun Paulus juga memiliki sudut pandangnya (dari pengalaman melayani dan menekuni hukum Taurat). Maka melalui teks 1 Korintus 7:12-16 Paulus memberikan nasehat kepada pasangan yang beriman bagaimana sikap yang ditunjukkan kepada pasangannya yang tidak beriman yaitu:

\section{Suami atau Istri Yang Beriman “Jangan Menceraikan' Pasangannya}

Menarik diri bukanlah alasan untuk bercerai, sebagaimana Paulus memberikan pertimbangkan ayat 15. Ray Sutton menjelaskan:

Alasan-alasan perceraian ini sama seperti menyembah berhala, sihir, ramalan, spiritisme, menghujat, bernubuat palsu, melanggar hari Sabat, membunuh (termasuk pelecehan fisik), menarik diri (secara badani dan seksual), dosa-dosa seksual, kegagalan berulang dari seorang bapa untuk menyediakan kebutuhan rumah tangga secara ekonomi, memberontak melawan otoritas alkitabiah dan bersumpah dengan maksud jahat. Rekan dari Rekonstruksi Kristen, Rousas Rushdooney, berbicara hal serupa. Pengakuan Westminster 24:6 mengamati dengan benar bahwa " Kerusakan manusia (adalah) sebegitu parahnya, sehingga ia cenderung mencari alasan-alasan untuk menceraikan dengan cara tidak sah apa yang telah Allah satukan dalam perkawinan." Tidak perduli tantangan, masalah dan kesedihan apa pun yang mungkin ada dalam pernikahan (1Kor. 7:26, 28, 32), percabulan adalah hanya alasan untuk bercerai (Mat. 5:32; 19:9), dan bahkan dalam kasus percabulan, mereka tidak seharusnya bercerai. ${ }^{94}$

Anjuran Paulus sebagai pertimbangan dari ayat sebelumnya yaitu ayat 11 kepada kaum yang mau bercerai memiliki dua pilihan, pertama adalah "tetap tidak menikah" bentuk waktu sekarang, menekankan keadaan yang tetap (1Kor. 7:11), di mana Kristus menyebutkan bahwa ada orang yang membuat dirinya demikian karena kemauannya sendiri oleh karena Kerajaan Sorga (Mat. 19:12). Pilihan lain adalah "didamaikan kembali" dengan pendampingnya (1Kor. 7:11), bentuk waktu aoris, menekankan peristiwa sekali untuk selamanya, tanpa ada perceraian sesudahnya. ${ }^{95}$

Tidak ada ijin yang diberikan untuk menikah kembali. Bahkan setelah bercerai, wanita tersebut dikatakan bahwa lelaki itu adalah masih "suaminya". Allah menciptakan ikatan dalam pernikahan. Allah juga yang memutuskan ikatan tersebut dengan kematian. Allah telah menciptakan laki-laki dan perempuan kemudian disatukan dalam sebuah ikatan pernikahan yang bersifat kekal. Kata "dipersatukan" dalam bahasa yunani adalah " $\sigma v v \varepsilon \xi \varepsilon v ~ \xi \varepsilon v "$ (sunezeuxen) dalam bentuk aorist, menunjukkan pada waktu yang tidak terbatas. Ini berarti pernikahan itu harus berlangsung seumur hidup. ${ }^{96}$ Allah Menyatukan dua orang dalam pernikahan dan hanya Dia yang dapat memutuskan ikatan tersebut (pada kematian).

\footnotetext{
${ }^{94}$ www.sarapanpagi.org > BELAJAR ALKITAB > Alkitab > Ucapan Paulus yang Sulit

${ }^{95}$ Charles F. Pfeiffer dan Everett F.Harrison, The Wayclifee Bible Commnetry ..., 620

96 W.E. Vine's, Complete Expository of Old And New Testament Words, (Thomas Nelson Publishers: Nashville Camdan, New York, 1985), 224
} 
Konteks ini bukan untuk melegalitaskan pernikahan beda agama dan perceraian. Dalam hal ini Paulus memiliki tujuan dalam menjawab persoalan jemaat Kristus bukan kepada pasangan yang mau menikah beda agama tetapi karena sudah terjadi pernikahan beda agama akibat penginjilan Paulus maka diperlukan petunjuk kebenaran yang harus dipahami sesuai dengan perkataan kebenaran Alkitab.

Karena itu dalam ayat 13 Paulus mengatakan seorang perempuan Kristen yang mempunyai suami bukan Kristen 'Jangan menceraikan' suaminya (dan sebaliknya ayat 15) kalau suaminya itu mau / rela terus hidup bersama dengan dia (Terjemahan BIS).

Menurut Marulak Pasaribu "perceraian adalah ciptaan manusia, refleksi dari keberdosaan dan penolakan manusia terhadap rencana semula ketika Tuhan menciptakan Pernikahan. Tuhan membenci perceraian". 97 Dosa tetap dosa dan perceraian adalah dosa karena dibenci Tuhan namun jika perceraian datang dari pihak luar maka perceraian dapat diterima sebagai suatu kenyataan yang harus dilakukan karena iman. ${ }^{98}$

Kata 'cerai' yaitu 'xorizo' artinya perceraian. Mengapa Paulus juga menyatakan bahwa orang beriman tidak boleh bercerai dengan pasangan yang tidak seiman karena Paulus memahami perkataan Tuhan Yesus dan Kitab PL tentang pernikahan dan perceraian. Yang dimaksudkan Paulus dengan larangan perceraian dan mengapa Paulus 'mengijinkan' perceraian dari orang yang tidak beriman sebagai berikut: Perceraian diperbolehkan dalam pandangan Paulus karena kasus perzinahan (1Korintus 6:16, 7:10-11, band. Matius 5:32, Matius 19:8, Maleakhi 2:14-16, Ulangan 24:1-4) namun ini bukan alasan pembenaran dalam perceraian karena Paulus memahami perceraian dibenci Allah, dan kasus di mana pihak pasangan yang tidak beriman tidak lagi menginginkan hidup bersama dengan suami atau istrinya yang beriman (ayat 15), maka perceraian diperbolehkan dan mungkin lebih baik dalam situasi seperti itu. Norman L.Geisler menyatakan 7 pandangan perceraian tak pernah dibenarkan;

1) perceraian melanggar rancangan Allah bagi perkawinan (komitmen monogamy seumur hidup), 2) perceraian melanggar ikrar yang dibuat dihadapan Allah (Amsal 27; Mal. 2:14), 3). Yesus mengutuk semua perceraian (Markus 10:1-9; Ulangan 22"13-19), 4) Rasul Paulus mengutuk perceraian, 5)perceraian membatalkan seorang seorang penilik jemaat (1 Tim. 3:2), 6) Pasangan pertama seseorang adalah pasangan yang sejati, 7) (perceraian melanggar tipologi yang sakral (Ef.5:32). ${ }^{99}$

Dalam penjelasannya ayat 12-15 sebagai berikut "Ketika pasangan yang tidak beriman itu berkeinginan untuk pergi, maka usaha untuk tetap mempertahankan dia dalam pernikahan itu hanya menciptakan ketegangan yang lebih besar dan konflik. Juga jika pasangan yang tidak beriman itu meninggalkan hubungan pernikahan secara permanen tetapi tidak bersedia untuk mengajukan cerai maka pasangan yang beriman akan berada dalam situasi sulit maka orang percaya dapat mengajukan cerai tanpa takut tidak memperkenan Allah". ${ }^{100}$

\footnotetext{
${ }^{97}$ Marulak Pasaribu, Pernikahan dan Keluarga Kristen, (Jawa Timur: Literatur I3, 2000), 151

98 Ibid., 158

${ }^{99}$ Norman L Geisler, Etika Kristen...., 362

${ }^{100}$ Pesankasihdarisurga.blogspot.com, diakses pada tanggal 15 Mei 2018
} 


\section{Hidup Dalam Damai sejahtera}

Hidup dalam damai sejahtera adalah panggilan Allah kepada manusia. Hidup damai dengan pasangan adalah adalah nasehat Rasul Paulus kepada jemaat di korintus khususnya bagi pasangan yang berbeda iman. Kalimat "tetapi Allah memanggil kamu untuk hidup dalam damai sejahtera, ${ }^{101}$ memberikan pengertian Allah memanggil untuk hidup rukun.

Kata 'damai sejahtera' dari kata "eıрฑv'n" (eirene) artinya tertib damai, perdamainan, keserasian; damai sejahtera; ketertiban; selamat. ${ }^{102}$ Kata itu memberikan pengertian bahwa pasangan suami istri di panggil untuk hidup dalam damai sejahtera, inilah sebabnya alasan mengapa Rasul Paulus menegaskan bahwa pasangan yang beriman kepada kristus tidak boleh menceraikan istrinya yang tidak beriman karena panggilan untuk hidup tertib dan rukun.

\section{Prinsip Hubungan Pasangan Suami Istri Yang Tidak Seiman}

Paulus mengingatkan bahwa kehendak Allah bagi pasangan suami istri adalah hidup dalam damai sejahtera, termasuk bagi pasangan yang tidak seiman. Karena Allah menghendaki pasangan yang belum diselamatkan akan menerima keselamatan, ada kemungkinan pasangan yang tidak beriman akan diselamatkan karena kesaksian yang baik dari istri atau suaminya yang beriman, itulah kehendak Allah. Oleh sebab itu Paulus memberikan keyakinan kepada pasangan suami atau istri yang beriman tentang bagaimana pernikahan pasangan yang tidak seiman bahwa suami atau istri yang tidak beriman kepada Kristus dikuduskan oleh pasangannya yang beriman, anak dari pasangan suami istri yang tidak seiman bukan cemar tetapi kudus dan pasangan yang beriman menyelamatkan pasangannya. Ini adalah prinsip-prinsip yang harus dipahami oleh pasangan suami istri yang tidak seiman, prinsip-prinsip ini dapat dijelaskan sebagai berikut:

\section{Suami Atau Istri Yang Tidak Beriman "Dikuduskan" Oleh Pasangannya Yang Beriman (Ayat 14)}

Rasul Paulus katakan dalam ayat 14 "karena suami yang tidak beriman itu 'dikuduskan' oleh istrinya dan istri yang tidak beriman itu 'dikuduskan' oleh suaminya..., Kata 'dikuduskan' dalam bahasa Yunani ' $\eta \gamma \iota \alpha \sigma \tau \alpha l$ ' (hegiastai) kasus perfek pasif indikatif orang ketiga tunggal yang menyatakan tindakan rampung atau sudah selesai, dengan kata dasar ' $\alpha \gamma i \alpha \varphi \omega$ ' (hagiaxo) yang memiliki arti mengkuduskan, menahbiskan, menghormati sebagai yang kudus. ${ }^{103}$ Tenses yang dipakai adalah perfek artinya bahwa proses pengudusan itu sudah berlangsung dulu dan hingga sekarang, saat surat ini ditulis oleh Paulus kepada jemaat Korintus. Jadi ayat 14 dapat diterjemahkan "karena suami yang tidak percaya itu telah sedang dikuduskan di dalam istri yang yang beriman..., dan istri yang tidak percaya itu telah sedang dikuduskan oleh saudara laki-laki yang beriman. Kata dikuduskan itu mengandung arti dipisahkan, telah dibuat diterima oleh Allah.

Paull Ellingworth menjelaskan bahwa kata 'dikuduskan oleh' dalam beberapa terjemahan diartikan dalam rangka keikutsertaan dalam keluarga besar umat Allah,

\footnotetext{
${ }^{101} 1$ Korintus 7:15

${ }^{102}$ Hasan Susanto..., 906

${ }^{103}$ Hasan Sutanto..., 905
} 
sehingga ada yang menterjemahkannya menjadi diterima oleh karena atau menjadi dekat dengan Allah atau dilayakkan untuk menjadi anggota umat Allah (BIMK). ${ }^{104}$

Dikuduskan bukan berarti pengudusan batiniah yang sejati seperti yang dikerjakan oleh Roh Kudus yang dari Tuhan Yesus. Karena pasangan tersebut dikatakan seolah "belum percaya" (14) dan tidak diselamatkan (16). Dikuduskan di sini tidak berarti bahwa pasangan yang percaya memiliki penghargaan yang lebih bagi iman Kristen dari kebanyakan orang yang belum percaya. Dikuduskan di sini juga tidak berarti bahwa pasangan yang belum percaya agaknya lebih diselamatkan daripada orang yang belum percaya yang lain. Singkatnya, sesuai dengan konteksnya, teks ini menyatakan bahwa pasangan yang belum percaya "dikuduskan", bukan "mungkin kelak dikuduskan" (secara batin dan rohaniah di masa depan).

Dalam hubungan pasangan pernikahan antara orang yang percaya dengan orang yang belum percaya, orang yang belum percaya tidak menajiskan pasangan yang Kristen. Anak Allah dapat hidup, makan, minum, bersekutu, tidur dan mengasuh anak-anak bersama pasangan yang belum percaya dengan kesadaran yang baik dan tidak ternodai. Bukan berarti orang percaya seharusnya menikahi orang yang belum percaya. Orang Kristen harus tahu bahwa Allah Tritunggal tidak memandang kehidupan pernikahannya dengan orang yang belum percaya sebagai tidak murni dan memalukan. Firman Allah menyetujui hubungan pernikahan orang yang percaya itu untuk dilanjutkan (hal ini bukan menyetujui pernikahan tidak seiman tetapi ini hanya bagi mereka yang menjadi pasangan suami istri karena salah satu dari pasangannya telah percaya kepada Kristus). Karena itu orang Kristen tidak boleh menceraikan pasangannya yang belum percaya (12-13). "Karena pasangan yang tidak beriman itu dikuduskan oleh pasangan yang sudah percaya.

Suami atau istri yang beriman menguduskan pasangannya yang tidak beriman artinya dilayakkan Allah menjadi anggota umat Allah karena pasangannya orang beriman. Suami atau istri beriman menjadikan pasangannya tidak cemar oleh karena imannya kepada Tuhan Yesus Kristus. Dalam hal 'menguduskan' bukan berarti iman yang Kristen itu secara otomatis dipindahkan kepasangannya yang tidak seiman. ${ }^{105}$ Orang tidak percaya diikutsertakan dalam keluarga besar umat Allah oleh karena iman orang beriman itu. Hal ini bukanlah berbicara masalah masuk surga atau tidak tetapi berbicara soal kehidupan masyarakat Kristen. ${ }^{106}$

\section{Suami atau Istri Yang Beriman "Menyelamatkan" Pasangannya}

Sekalipun suami atau istri yang beriman hanya sebagai kemungkinan untuk menyelamatkan pasangannya namun ini menjadi salah satu alasan yang kuat untuk mempertahankan rumah tangganya. Menjadi salah satu alasan untuk tidak boleh bercerai karena keselamatan pihak yang satunya itu mungkin dapat dicapai dengan mempertahankan ikatan pernikahan. ${ }^{107}$ BIMK menterjemahkan 1 Korintus 7:16, sebagai berikut;

${ }_{105}^{104}$ Paul Ellingworth, Howard Hatton, Pedoman Penafsiran Alkitab ..., 174

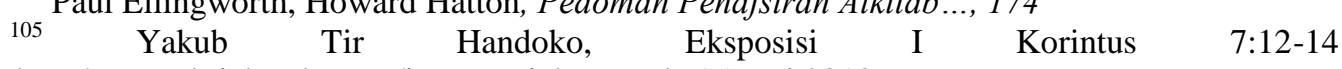
Online:http:/www.gkrieksodus.org/imagr. Diakses pada 15 Mei 2018

106 Ibid..., 175

${ }^{107}$ Charles F.Pfeiffer, The Wycliffe Bible Commentary, (Jawa Timur: Gandum Mas, 2001), 622 
"Karena saudara sebagai istri yang sudah percaya kepada Tuhan bagaimanakah saudara bisa tahu dengan pasti bahwa saudara tidak dapat menyelamatkan suamimu? Begitu juga saudara sebagai suami Kristen, bagaimanakah saudara bisa tahu dengan pasti bahwa saudara tidak dapat menyelamatkan istrimu?

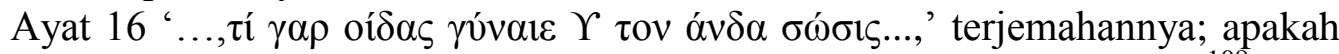
sebab engkau tahu, hai istri jika suami (mu) engkau akan menyelamatkan?.' ${ }^{108}$ Kata 'engkau akan menyelamatkan" bukan kepada orang yang tidak benar tetapi kata ini mengikuti yang artinya dari orang beriman akan bisa menyampaikan berita keselamatan dengan kesaksian hidupnya dan kalau Tuhan menyelamatkan pasti akan selamat.

Mempertahankan pernikahan bertujuan supaya melalui sikap yang beriman terdorong untuk bersaksi dan semakin mengasihi pasangannya supaya membuka jalan mengenal Tuhan untuk mendapatkan anugerah keselamatan. Dalam tafsiran Wyclife katakan alasan untuk tidak boleh bercerai ialah karena keselamatan pihak yang satunya itu mungkin dapat dicapai dengan mempertahankan ikatan pernikahan. ${ }^{109}$

Jadi prinsip utama dalam pernyataan Paulus tersebut adalah Allah menghendaki pasangan yang belum diselamatkan ini, terselamatkan oleh pasangannya yang sudah percaya melalui sikap atau kesaksian pasangannya yang beriman kepada Kristus.

Keselamatan adalah tindakan pribadi, namun bagian-bagian Alkitab menjelaskan dan menyiratkan janji keselamatan seluruh rumah tangga jika ada satu orang beriman dalam keluarga itu adalah orang percaya, misalnya: seperti KPR 11:14 yang mengindikasi janji yang diberi kepada Kornelius bahwa rumah tangganya akan diselamatkan; Mereka tidak diselamatkan hanya karena Kornelius percaya melainkan karena mereka sendiri (anggota keluarga) mau ikut percaya. Kesaksian hidup dari orang percaya bisa menyelamatkan yang tidak percaya.

Satu bagian lain dalam kitab Kisah yang mengandung janji keselamatan rumah tangga ditemukan dalam Kisah 16:31. Disini seorang sipir penjara Filipi bertanya, "Tuan-tuan, apakah yang harus aku perbuat, supaya aku selamat?" Kepadanya Paulus dan Silas menjawab, "'Percayalah kepada Tuhan Yesus Kristus dan engkau akan selamat, engkau dan seisi rumahmu." Sekali lagi, yang diajarkan ini konsisten dengan setiap ayat Alkitab mengenai keselamatan. Secara pribadi orang mendengar Injil dan merespon dengan iman dan pasti diselamatkan. Mereka tidak diselamatkan bukan karena mereka adalah anggota keluarga sipir penjara; sebaliknya, mereka diselamatkan karena mereka mempercayai pesan Injil dan meresponi dengan iman.

Pertanyaan retoris Paulus dalam 1 Korintus 7:16: "Sebab bagaimanakah engkau mengetahui, hai isteri, apakah engkau tidak akan menyelamatkan suamimu? Atau bagaimanakah engkau mengetahui, hai suami, apakah engkau tidak akan menyelamatkan isterimu?" Jawabannya adalah mereka tidak tahu karena hanya Allah yang tahu siapa yang diselamatkan dan siapa yang tidak. Karena itu Paulus mengajarkan untuk tidak bercerai untuk bertahan dengan kemungkinan Allah bisa menyelamatkan pasangan yang belum percaya tersebut.

\footnotetext{
${ }^{108}$ Hasan Sutanto, Perjanjian Baru..., 906

${ }^{109}$ Charles F.Pfeiffer, The Wycliffe Bible Commentary..., 622
} 


\section{Anak Dari Pasangan Suami Istri Yang Tidak Seiman Adalah "Kudus"}

Paulus menyampaikan bahwa pemikiran dari ayat 14 tentang "andaikata tidak demikian, niscaya anak-anakmu adalah anak cemar, tetapi mereka adalah anak-anak kudus" Kata 'andaikata' ini sebuah kata pengandaian (yang tidak sesuai kenyataan dan merupakan lawan dari 'tetapi sekarang...' (diartikan padahal yang sebenarnya). Persoalan pernikahan yang berdampak kepada status anak (anak yang dimaksudkan pada anak anak dari hasil pernikahan beda iman saja).

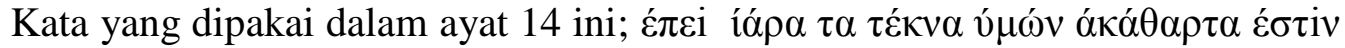

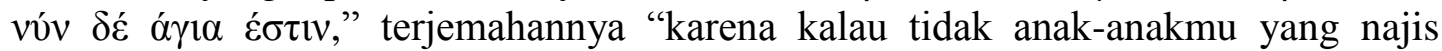
adalah, sekarang tetapi mereka kudus." terjemahan BIS kalau tidak begitu anak-anak mereka tentunya seperti anak-anak kafir padahal anak-anak dianggap sebagai anggota umat Allah. ${ }^{110}$

Kemungkinan banyak orang berpendapat bahwa anak yang dihasilkan dalam pernikahan beda agama status anaknya cemar. Hal ini bisa saja menimbulkan konflik dalam pemikiran dan batin anak sehingga menghambat spiritual, mental dan moralnya. Kata cemar disini diartikan kafir, anak-anak penyembah berhala, najis dipandangan Allah. Howart mengartikannya "tidak suci", "tidak murni","najis", "tercemar"111

Mengenai 1 Korintus 7:14: " Paulus tentunya tidak berkata bahwa suami yang tidak percaya diselamatkan oleh iman istri yang percaya. Dengan jelas hubungan pernikahan tersebut dikuduskan sehingga perceraian tidak dibutuhkan. Dalam Tafsiran Waycliif menjelaskan bahwa persatuan itu sah dan memberikan hak-hak atas perlindungan Allah dan kesempatan untuk berhubungan erat dengan salah satu anggota keluarga Allah. Hal ini bisa melapangkan jalan menuju ke pertobatan bagi orang yang belum percaya itu. ${ }^{112}$

Jika dikaitkan dengan keselamatan; anak-anak yang kudus dari pasangan tidak seiman ini karena salah satu orang tuanya percaya Tuhan Yesus maka jika kemudian hari anak-anak ini memilih percaya kepada Kristus secara pribadi maka keselamatan menjadi bagian hidupnya statusnya menjadi anak Allah yang kudus.

\section{KESIMPULAN}

Dari bentuk-bentuk Pastoral Konseling yang sudah diuraikan di atas, maka dari 1 Korintus 7:12-16, ada 4 nasehat Pastoral Konseling yang dilakukan Paulus kepada jemaat Korintus bagi pasangan yang tidak seiman, nasehat tersebut diberikan untuk memberikan solusi atas pertanyaan dan persoalan yang dihadapi, dialami jemaat Korintus. Nasehat tersebut adalah model pastoral konseling bagi pasangan yang tidak seiman yaitu; Model Pastoral Konseling Edukatif, Supportif, Model Spiritual, dan Model konfrontatif.

\section{Model Pastoral Konseling Edukatif}

Persoalan yang dihadapi jemaat Korintus dari I Korintus 7:12-16 adalah tentang perkawinan yang sedang dihadapi pasangan yang tidak seiman. Kondisi yang

${ }^{110}$ Hasan Sutanto, Perjanjian Baru..., 906
${ }^{111}$ Paul Ellingworth, Howard Hatton..., 175
${ }^{112}$ Charles F. Pfeiffer dan Everett F.Harrison, The Wayclifee Bible Commentary..., 621 
diperhadapkan kepada Paulus sebagai konselor, Paulus menggunakan pastoral konseling edukatif yaitu Paulus memberikan pengajaran firman Tuhan.

Pengajaran Rasul Paulus mengenai pasangan suami istri yang tidak seiman adalah suami yang beriman tidak boleh menceraikan istrinya yang tidak beriman, hidup dalam damai sejahtatera Tuhan, prinsip yang diajarkan Paulus adalah suami atau istri yang beriman menguduskan pasangannya yang tidak seiman, Menyelamatkan pasangannya dan anak-anak dari pasangan suami istri yang tidak seiman adalah kudus. selanjutnya kepada pasangan yang seiman disampaikan sesuai dengan kebenaran firman Tuhan bahwa pernikahan yang dikehendaki Allah; harus dengan seiman dan tidak diijinkan untuk melakukan perceraian jika sudah terjadi dalam pernikahan ada pasangan yang tidak seiman. Dasarnya Paulus memahami bahwa apa yang dipersatukan Allah tidak bisa diceraikan oleh manusia. Pengajaran itu disampaikan kepada salah satu pasangan yang percaya Tuhan Yesus; bagaimana sikap yang seharusnya dilakukan dan ketetapan yang dipegang dalam ajaran firman Tuhan. ${ }^{113}$

\section{Model Pastoral Konseling Spiritual}

Dalam I Korintus 7:12-16 menjelaskan dalam kehidupan pasangan suami istri yang tidak seiman mereka menghadapi krisis kerohanian; ada yang percaya Tuhan dan pasangannya ada yang tidak percaya, persoalan status pasangan tidak seiman dan anak-anak 'sebagai orang cemar', dan akibat yang akan mereka dapatkan kemungkinan terjadi 'perceraian'.

Persoalan inilah yang Paulus selesaikan melalui kebenaran firman Tuhan. Paulus menjelaskan bahwa pasangan yang tidak seiman ini akan dikuduskan dan diselamatkan oleh pasangannya, keberadaan pernikahan dalam keluarga dilarang ada perceraian dari pihak pasangan yang beriman karena Allah tidak memperbolehkan perceraian, status anak-anak bukanlah anak-anak cemar tetapi mereka adalah anakanak kudus karena orang tua yang percaya Tuhan, Kalau pun terjadi perceraian orang percaya harus hidup seperti panggilan Tuhan yaitu hidup damai sejahtera (ayat 15c)

\section{Model Pastoral Konseling Konfrontatif}

Pastoral Konseling yang Paulus pakai untuk mengkonfrontasi melalui dengan kebenaran Firman Tuhan dengan masalah keputusan dalam bertindak; apa yang harus diambil oleh pasangan yang tidak seiman untuk masalah pernikahannya sesuai dengan kebenaran atau perintah Tuhan.

Pemikiran Paulus ada 3 yaitu tidak boleh bercerai, bercerai karena pasangan yang tidak seiman yang meminta, dan tidak terikat pasangan yang percaya Tuhan dengan pasangannya yang tidak seiman. Menurut Dale Mathis "pernikahan adalah kontrak secara resmi, sosial, dan rohani antara seorang pria dan wanita. Pernikahan merupakan janji ilahi yang dibuat dihadapan Allah. Ini adalah komitmen satu sama lain - ikrar untuk hidup saling melayani, dan tetap setia satu sama lain. Pernikahan juga merupakan cara Allah untuk menunjukkan kasih-Nya bagi kita dan rencanaNya

${ }^{113}$ Bab II., 38 
bagi pernikahan kepada dunia, dan membantu kita menjadi lebih serupa dengan Dia" $" 114$.

Akhir dari tujuan pastoral konseling konfrontatif adalah membuat kesadaran; pertama perlunya perubahan watak dan tingkah laku, disini pasangan yang beriman harus menempatkan dirinya sebagai orang percaya yang sungguh-sungguh mengasihi Tuhan Yesus. Disini konseli harus dapat mengakui hal-hal yang salah bahkan dosa harus diselesaikan untuk dibaharui misalnya keputusan menikah dengan pasangan tidak seiman, karena penginjilan, dirinya menjadi percaya tetapi pasangannya belum percaya, keraguan terhadap perintah pernikahan dan perceraian yang dimaksudkan dalam firman Tuhan. Kedua bersifat pribadi, disini konseli diarahkan dan diminta menyesuaikan diri dengan prinsip Alkitab, misalnya apapun yang menjadi keputusan pasangan yang tidak seiman dia harus siap. Ketiga, mengubah dengan menkonfrontasi Alkitabiah dengan hidup konseli, disini membuat konseli diperhadapkan dengan pilihan berdasarkan firman Tuhan bahwa dirinya harus menguduskan dan menyelamatkan pasangannya. Keempat, pusatnya adalah penyucian hati, pembentukan iman, dan ketulusan hidup, maksudnya konseli belajar berjalan dalam ketaatan firman Tuhan menjalani kehidupan pernikahannya dengan damai sejahtera.

\section{Model Pastoral Supporting}

Firman Allah mengajarkan orang percaya untuk saling mengasihi, menguatkan dan mendukung satu sama lain (1Tes. 5: 11; Ibr. 3: 13; 10:25) tujuannya agar konseli dalam persekutuan umat Tuhan didorong untuk menghadapi masalahnya dengan benar, mendiskusikan perasaan bersalah, kenyataan hidup yang dihadapi, yang pada akhirnya mampu untuk menerimanya kenyataan dalam hal-hal yang tidak bisa diubah kembali (seperti cacat, kematian), percaya dan sabar serta menyerah kepada Tuhan (Mat. 11: 28-30). Dalam Pastoral konseling supporting seorang konselor memberikan perhatian khusus, mendukung dan mendorong konseli untuk menghadapi masalahnya dalam takut akan Tuhan.

Rasul Paulus memberikan perhatian khusus kepada jemaat di Korintus khususnya kepada pasangan suami istri yang tidak seiman, dimana Rasul Paulus mendukung hubungan tersebut untuk tetap hidup sebagai pasangan suami istri yang tidak seiman, hal ini bukan berarti rasul Paulus setuju dengan pernikahan yang tidak seiman, tetapi karena salah satu pasangan tersebut telah percaya kepada Kristus oleh karena penginjilan namun tetap hidup sebagai pasangan suami istri sehingga tidak seiman. Rasul Paulus memberikan nasehat, dukungan, perhatian agar suami atau istri yang beriman mempertahankan rumah tangganya karena panggilan untuk hidup dalam damai sejahtera.

114 Dale Mathis dan Susan Mathis, Menuju Pernikahan Yang Sehat Dan Solid, (Yogyakarta: Andi, 2014), 12 


\section{DAFTAR PUSTAKA}

Abineno, J.L. Ch

2011 Pedoman Praktis Untuk Pelayanan Pastoral, Jakarta: BPK Gunung Mulia.

Abineno, J. L. Ch

2010 Sekitar Etika Dan Soal-Soal Etis, Jakarta: BPK Gunung Mulia.

Alexander, Daniel

2006 Keluarga Yang Disukai Tuhan, Yogyakarta: ANDI

Alwi, Hasan

nd $\quad$ Kamus Besar Bahasa Indonesia

Anselm, Strauss \& Juliet Corbin

1990 Basic of Qualitative Research Grounded Theory Procedure and

Techniques, Newbury Park: Sage Publication

Aqib, Zainal

2014 Ikhtisar Bimbingan Konseling, Bandung: Yrama Widya

Barker, Kenneth L

2002 NIV Study Bible, Zondervan: Grand Rapids, Michigan

Beek, A.Van

2011 Pendampingan Pastoral, Jakarta: BPK Gunung Mulia

Borrong, Robert

2006 Etika Seksual Kontemporer, Bandung: Ink Media.

Bons Storm, M

1988 Apakah Penggembalaan Itu; Petunjuk Praktis Pelayanan Pastoral, Jakarta: BPK Gunung Mulia

Bogdan, Robert \& Sari Knopp Biklen

1982 Qualitative Research for Education: An. Introduction to Theory and Methods, Boston: Allyn and Bacon Inc

Crabb, Larry

1999 Prinsip Dasar Konseling, peny, Yefta Bastian, pen, Andreas A. P. Sitanggang, Jakarta: Yayasan Pekabaran Injil Immanuel.

Cole, Edwin Louis

2011 Kesempurnaan Seorang Pria, Jakarta: Metanoia 
Douglas, J.D

1992

Ensiklopedi Alkitab Masa Kini, Jilid I (A-L), (Jakarta: Yayasan Bina Kasih/OMF.

DPH, E. Oswari

1982 Keluarga Idaman, Jakarta: BPK Gunung Mulia

Ellingworth, Paul \& Howard Hatton

2010 Pedoman Penafsiran Alkitab; Surat Paulus Yang Pertama Kepada

Jemaat di Korintus, Jakarta: Lembaga Alkitab Indonesia

Ellingworth, Paul

2010 Surat Paulus yang Pertama Kepada Jemaat Di Korintus, Jakarta: LAI

Geisler, Norman L

2003 Etika Kristen, Malang: Literatur SAAT.

Gintings, E. P

2009 Konseling Pastoral; Penggembalaan Kontekstual, Bandung: Bina

Media Informasi.

Green, Jay P

1982

The Interlinear Bible Hebrew-English, Michigan: Baker Book House

Guthrie, D, dkk

1983 Tafsiran Alkitab Masa Kini, Jilid 3, Jakarta; BPK Gunung Mulia.

Gunadi, Paul

2007

How To Enjoy Your Marriage, Yogyakarta: Gloria Graffa.

Hawari, Dadang

1997 Ilmu Kedokteraan Jiwa dan kesehatan Jiwa, Yogyakarta: Dana Bhakti Prima Yasa

Hiltner, Steward

1992 Teologi dan Praksis Pastoral; Antologi Teologi Pastoral, Jakarta: BPK Gunung Mulia

Hommes, Tjaard G

1992

Teologi Dan Praksis Pastoral, Jakarta: BPK Gunung Mulia.

Lahaye, Tim

2002

Kebahagiaan Pernikahan Kristen, (Jakarta: BPK Gunung Mulia 
Les dan Leslie Parrot

2001 Relationships, Batam: Gospel Press

Lumintang, Stevri Indra \& Danik Astuti Lumintang

2016 Theologia Penelitian dan Penelitian Theologis, (Jakarta: Geneva Insani Indonesia

Manaransyah, Ni Wayan Martha

2003 Perempuan Bijak, Batu: Dept Literatur YPPII.

Mathis, Dale \& Susan Mathis

2014 Menuju Pernikahan Yang Sehat Dan Solid, Yogyakarta: Andi

Moleong, Lexy. J

2010 Metodologi Penelitian Kualitatif, Bandung: Penerbit PT Remaja Rosdakarya

Pasaribu, Marulak

2000 Pernikahan dan Keluarga Kristen, Jawa Timur: Literatur I-3

Pfitzner, V.C

2000 Kesatuan Dalam Kepelbagaian: Tafsiran Atas Surat 1 Korintus, Jakarta: BPK Gunung Mulia

Pfeiffer, Charles F Everett.F.Harrison

2001 The Wycliffe Bible Comentary, Vol.3, Malang:Gandum Mas

Pink, A.W

2002 Tafsiran Injil Yohanes, Surabaya: Yakin

Piper, John

2012 Apa Yang Yesus Tuntut Dari Dunia, Malang: Literatur SAAT

Piper John dan Justin Talylor

2011 Sex dan Supremasi Kristus, Surabaya: Momentum

Piper, John

2016 This Momentary Marrige, Bandung: Pioner Jaya

Ptitzner

1985 Tafsiran atas surat I Korintus, Jakarta:BPK Gunung Mulia

R.C, Sproul

1975 Discovering the intimate Marriage, Minnesota: Bethany Fellowship 
Ridderbos, Herman

2008 Paulus Pemikiran Utama dan Theologianya, Surabaya: Penerbit Momentum

Rohde, $\mathbf{J}$

nd in Horst and Gerhard,Exegetical Dictionary of The New Testament Volume III, Grand Rapids: William B. Eerdmans Publishing Company

Scheunemann, Volkhard Gerlinde

nd Hidup Sebelum dan Sesudah Nikah, Batu: Dept Literatur YPPII.

Schnabel, Eckhard J

2010 Rasul Paulus Sang Misionaris, Yogyakarta: Penerbit Andi.

Situmorang, Jonar

2016 Berani Menikah, Jogyakarta: Penerbit Andi.

Slayton, Gregory W

2015 Be A Better Dad Today, Jakarta: Persekutuan Gereja-Gereja Tionghoa Indonesia.

Spradley, James $\mathrm{P}$

1997 Metode Etnografi, (Yogyakarta: PT. Tiara Wicana,), 56-200, dan dalam buku James P. Spradley, Participant Observation, (New York: Holt, Rinehart and Winston.

Stott, Jhon

1984 Isu-isu Global: Menantang kepemimpinan Kristiani, Jakarta: Yayasan Komunikasi Bina kasih/OMF.

Sugden, Howard F

1982 Prioritas Seorang Pendeta, Malang: Gandum Mas.

Subeno, Sutjipto

2008 Indahnya Pernikahan Kristen, Surabaya: Momentum

Sugiyono

2016 Metode Penelitian Kuantitatif, Kualitatif, Bandung: Alfabeta

Susabda, Yakub

2004 Pembinaan Keluarga Kristen, Bandung: Mitra Pustaka

Susabda, Yakub B

1985 Pastoral Konseling Jilid I, Malang: Gandum Mas 
Sutanto, Hasan

2002 Perjanjian Baru Interlinear Yunani - Indonesia Dan Konkordansi

Perjanjian Baru, Jakarta: LAI

Soesilo, Vivian A

2010 Bimbingan Pranikah, Malang: Literatur SAAT

Sosipater, Karel

2010 Etika Perjanjian Lama, Jakarta: Suara Harapan Bangsa.

Thomas, Gary

2013 Sacred Marriage, Jakarta: Yayasan Gloria

Thomson, J.G.S.S

2007 Ensiklopedi Alkitab Masa Kini, Jilid II, Jakarta: Yayasan Bina Kasih OMF

Tong, Stephen

1991 Keluarga Bahagia, Jakarta: Percetakan Timur Agung

To'u, Tulus

2007 Dasar-Dasar Konseling Pastoral, Yogyakarta: Andi

Trisna, Jonathan A

2013 Two Become One, Jogjakarta: Penerbit Andi

Unarto, Erich

2007 Hidup Dalam Etika Kristen, Jakarta: Pustaka Sorgawi

Vance, Carol

2010 Raih Mahkotamu, Malang; Gandum Mas

Van Beek, Aar Martin

1992 Konseling Pastoral, Semarang: Satya Wacana

Vangemeren, Willem A

2007 Penginterpretasian Kitab Para Nabi, Surabaya; Momentum

Vaux, De

1961 Marriage, USA: MC.Grow-Hill

Vine's, W.E

1985 Complete Expository of Old And New Testament Words, Thomas Nelson Publishers: Nashville Camdan, New York 
Wijaya, Andik

2014 Sexual Holiness, Surabaya: Kenza Publishing House

Wijanarko, Jarot

2017 Pemulihan Pria Sejati Dan Wanita Bijak, Jogjakarta: Penerbit ANDI

Wise Carrol A \& John R

1962 Cavanag, Fundamental Pastoral Counseling; Technic and Psychology, Milwaukee: The Bruce Publishing Company

Yin, Robert K

2013 Study Kasus: Desain dan Metode, Jakarta: PT Raja Grafindo Persada 